\title{
THE RIGHT TO SCIENCE AND CULTURE
}

\section{LEA SHAVER*}

The Universal Declaration of Human Rights states: "Everyone has the right freely to participate in the cultural life of the community, to enjoy the arts and to share in scientific advancement and its benefits." This Article suggests how this text may offer a philosophical and legal basis to constrain the further expansion of protectionism in international IP law.

Drawing on accepted methodologies of human rights interpretation and recent research from legal and economic scholars on the value of preserving the knowledge commons, the Article offers a theory of "the right to science and culture" as requiring a public goods approach to knowledge innovation and diffusion. The Article then translates this public goods theory into concrete guidance for policy makers seeking to implement human rights obligations, and for jurists asked to adjudicate rights-based challenges to copyright and patent laws. In conclusion, this Article suggests that reviving attention to this long-marginalized provision of international public law may provide an important rhetorical and legal tool with which to open up new possibilities for sensible IP reform.

Introduction

I. Article 27 in Historical Perspective

A. Expanding Access to Science and Culture ................137

B. Protecting the Interests of Authors ......................144

C. From 1948 to the Current Crossroads .....................151

II. A Theory of the Right to Science and Culture ................154

A. Knowledge as a Global Public Good....................156

B. Socioeconomic Rights and Universal Access ............. 163

* Lea Shaver is an Associate Research Scholar and Lecturer in Law at Yale Law School, where she is a Faculty Fellow of the Information Society Project. Her recent publications include: ACCESS TO KNOWLEDGE IN EGYPT: NEW RESEARCH ON INTELlECTUAL PROPERTY, INNOVATION AND DEVELOPMENT (2010) (with co-editor Nagla Rizk); ACCESS TO KNOWLEDGE IN BRAZIL: NeW RESEARCH ON INTELlECTUAL Property, InNovation and DeVelopment (2010); and Defining and Measuring A2K: A Blueprint for an Index of Access to Knowledge, 4 I/S: J.L. \& POL'Y FOR INFO. SoC'Y 235 (2008). The author would like to thank Jack Balkin, Robert Burt, Laura DeNardis, William Eskridge, Christine Jolls, and Carol Rose of Yale Law School; Amy Kapczynski of UC Berkeley Law School; Frank Pasquale of Cardozo Law School; Madhavi Sunder and Anupam Chander of UC Davis Law School; Laurence Helfer and Jerome Reichman of Duke Law School; Nora Demleitner, Akilah Folkami Daniel Greenwood, Julian Ku, and Norman Silber of Hofstra Law School; Danielle Citron, Mark Graber, and David Super of the University of Maryland Law School; Caterina Sganga of Scuola Superiore Sant'Anna; and Eve Gray and Andrew Rens of the University of Cape Town for their helpful comments during the development of this work. Broader thanks are also due to the exceptionally collegial faculties at both Hofstra Law School and the University of Maryland Law School for welcoming the workshopping of this Article, and for their valuable criticism and feedback. 
C. Reconciling Access and Protection........................169

III. Implications for Intellectual Property Law ................... 174

A. The Legal Status of the Right to Science and Culture .....175

B. Implications for International IP Law....................179

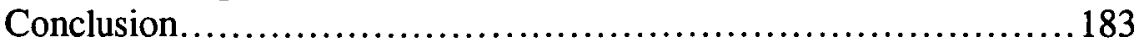

\section{INTRODUCTION}

Everyone has the right freely to participate in the cultural life of the community, to enjoy the arts and to share in scientific advancement and its benefits.

Everyone has the right to the protection of the moral and material interests resulting from any scientific, literary or artistic production of which he is the author.

-Article 27, Universal Declaration of Human Rights ${ }^{1}$

To date, the interaction between human rights law and intellectual property law has been considered in three veins. The first approach asserts that intellectual property rights are in fact human rights. This approach suggests that there is little or no conflict between internationally accepted human rights norms and the expansion of IP protections. ${ }^{2}$ A second approach focuses on conflicts between human

1. Universal Declaration of Human Rights, G.A. Res. 217A, art. 27, U.N. GAOR, 3d Sess., 1st plen. mtg., U.N. Doc. A/810 (Dec. 10, 1948) [hereinafter Universal Declaration].

2. See, e.g., U.N. Econ. \& Soc. Council [ECOSOC], Comm. on Econ., Soc. \& Cultural Rights, Working Paper: Trade and Human Rights: What's at Issue?, Part III.C., 25th Sess., U.N. Doc. E/C.12/2001/WP.2 (May 7, 2001) (prepared by Hoe Lim) (asserting that Article 15(1)(c) of the ICESCR protects "the human right to intellectual property protection"); The Secretary-General, Intellectual Property Rights and Human Rights: Report of the Secretary-General, Part III.G.1-2, delivered to the Sub-Comm'n on the Promotion \& Protection of Human Rights, 52d Sess., U.N. Doc. E/CN.4/Sub.2/2001/12 (June 14, 2001) [hereinafter Report of the Secretary-General] (reporting the International Publisher Association's question concerning the existence of any conflict between TRIPS implementation and the realization of "other human rights"); id. at Part III.H (reporting the argument of the Max Planck Institute that the situation of intellectual property and human rights "is one of balance rather than conflict" since "at least the main types of intellectual property are human rights"); E.S. Nwauche, Human Rights-Relevant Considerations in Respect of IP and Competition Law, 2 SCRIPT-ED 467, 468 (2005), available at http://www.law.ed.ac.uk/ahrc/scrip t-ed/vol2-4/utopia.pdf (describing what I term as "the right to science and culture" as "the right to intellectual property"). Several scholars have put forward more nuanced versions of this argument, arguing that intellectual property protections consist of both elements required by human rights, as well as some elements not grounded in human rights. Audrey R. Chapman, Towards an Understanding of the Right to Enjoy the Benefits of Scientific Progress and its Applications, 8 J. Hum. RTs. 1, 19-20 (2009) [hereinafter Chapman, Towards an Understanding]; Peter K. Yu, Reconceptualizing 
rights and IP in particular areas, such as the rights to health, food, and education. This second approach suggests that the current international IP regime may be fine as a general matter, but requires tailoring to protect competing values in particular areas, such as copyrights in educational materials, and patents on pharmaceutical products and crop varieties. ${ }^{3}$ More recently, a third approach is emerging, asserting that the right to development is threatened by international IP rules that impede technology transfer and the emergence of younger industries. This approach suggests that higher protections for IP are appropriate

Intellectual Property Interests in a Human Rights Framework, 40 U.C. DAvis L. REv. 1039 (2007) [hereinafter Yu, Reconceptualizing]; Peter K. Yu, Ten Common Questions About Intellectual Property and Human Rights, 23 GA. ST. U. L. REv. 709, 709-12 (2007) [hereinafter Yu, Ten Common Questions]; ECOSOC, Comm. on Econ., Soc. \& Cultural Rights, Discussion Paper: Approaching Intellectual Property Rights as a Human Right: Obligations Related to Article 15(1)(c), 24th Sess., U.N. Doc. E/C.12/2000/12 (Oct. 3, 2000) (submitted by Audrey R. Chapman). This version of the argument maintains the premise that both patent and copyright protection are required by human rights law, but does not discount the possibility of conflict between particular implementations of IP and human rights. Other scholars have expressed concern that the subtleties of this argument may be lost on IP decision-makers. Kal Raustiala suggests that:

[T] he risk is that the language and politics of human rights, as it filters into the language and politics of IP rights, will make it harder for governments to resist the siren songs of those seeking ever more powerful legal entitlements. It remains to be seen whether the marriage of human rights and IP will make international IP rights more socially just, or just more powerful.

Kal Raustiala, Commentary: Density and Conflict in International Intellectual Property Law, 40 U.C. Davis L. Rev. 1021, 1037 (2007).

3. See, e.g., Report of the Secretary-General, supra note 2, at Part I.A. (highlighting Brazil's comments concerning the "right to health"); id. at Part I.B.3(b) (highlighting Pakistan's comments concerning the rights to health, education and food); id. at Part I.C. (highlighting the comments of the German Commission of Justice and Peace on the rights to food and health); Statement by the Comm. on Econ., Social \& Cultural Rights to the U.N. Comm. on Econ., Soc. \& Cultural Rights, Human Rights \& Intellectual Property, U.N. Doc. No. E/C.12/2001/15, 12, (Nov. 26, 2001) [hereinafter CESCR] ("The Committee wishes to emphasize that any intellectual property regime that makes it more difficult for a State party to comply with its core obligations in relation to health, food, education, especially, or any other right set out in the Covenant, is inconsistent with the legally binding obligations of the State party."); Audrey R. Chapman, The Human Rights Implications of Intellectual Property Protection, 5 J. INT'L ECON. L. 861 (2002) (highlighting several human rights potentially impacted by IP protection, with emphasis on the right to health); Kevin R. Gray, Right to Food Principles Vis-à-Vis Rules Governing International Trade (British Inst. of Int'l \& Comparative Law, 2003), available at http://www.cid.harvard.edu/ cidtrade/Papers/gray.pdf (recommending use of TRIPS flexibilities to avoid jeopardizing the right to food). 
for developed countries such as the United States, but that limits and exceptions should be permitted for emerging economies. ${ }^{4}$

This Article proposes a fourth approach to analyzing the interaction of intellectual property protections with human rights norms. In contrast to the three preceding approaches, I suggest that international IP law is in tension with human rights norms not only in certain narrow instances, but systematically. To the extent that IP protections transform creativity, information, science, and technology from public goods into private ones, I argue that they are fundamentally in tension with what I shorthand as "the right to science and culture." This premise need not motivate the conclusion that IP protections must be abolished, but it does require that such protections be carefully considered and justified, with attention to the often negative impact on access to knowledge. Legal scholars, most notably Laurence Helfer, have previously noted the potential of human rights arguments to constrain the otherwise unchecked expansion of IP protection. ${ }^{6}$ I

4. See, e.g., Kaitlin Mara \& James Leonard, Experts Aim to Balance Intellectual Property Rights and Human Rights, InTELl. Prop. WATch, May 15, 2009, http://www.ip-watch.org/weblog/2009/05/15/experts-aim-to-balance-intellectual-proper ty-rights-and-human-rights/ (describing the interest of the United Nations Working Group on the Right to Development in international intellectual property policy and quoting the chair of the group as saying that the challenge is to balance IP protections usefulness as incentives with the need to protect human rights); U.N. Human Rights Council, Working Group on the Right to Dev., Desk Review of the Intergovernmental Working Group on Public Health, Innovation and Intellectual Property from a Right to Development Perspective, II 101, 104, U.N. Doc. A/HRC/12/WG.2/TF/CRP.5 (Mar. 27, 2009) (prepared by Lisa Forman), (praising the IGWG process for encouraging developing countries to take full use of TRIPS flexibilities, but criticizing the process for failing to emphasize the importance of such countries avoiding the imposition of TRIPS-plus measures in bilateral trade treaties, from the overall perspective that lower and more lenient IP protections in developing countries are favourable to the realization of the right to development). The relevance of the right to development was also foreshadowed in the 2001 statement of the CESCR, supra note 3, at 19 1-2, 4 .

5. As explained at notes 123 to 126 and accompanying text, the term "right to science and culture" is not yet in general use, but is my proposed shorthand for the right recognized, inter alia, at Article 27 of the Universal Declaration; Article 15 of the International Covenant on Economic, Social and Cultural Rights; Article 31 of the Children's Convention; and Article XIII of the American Declaration. Universal Declaration, supra note 1; International Covenant on Economic, Social and Cultural Rights, G.A. Res. 2200A (XXI), art. 15, U.N. GAOR, 21st Sess., Supp. No. 16, Annex, U.N. Doc. A/6316 (Dec. 16, 1966) [hereinafter ICESCR]; Convention on the Rights of the Child, G.A. Res. 44/25, art. 31, U.N. GAOR, 44th Sess., Supp. No. 49, Annex, U.N. Doc. A/44/49 (Nov. 20, 1989); Organization of American States, American Declaration of the Rights and Duties of Man, art. XIII, adopted by the Ninth International Conference of American States, 1948, reprinted in ORGANIZATION OF American States, Basic Documents Pertaining to Human Rights in the INTERAMERICAN SYSTEM 17, 20 (1992) [hereinafter American Declaration].

6. Laurence R. Helfer, Human Rights and Intellectual Property: Conflict or Coexistence?, 5 MinN. InTELl. Prop. Rev. 47, 57-59 (2003) (suggesting human rights 
suggest that this fourth form of the human rights argument can provide the firmest foundation for thorough and meaningful reform.

In making this argument, my work is informed by the emerging "access to knowledge" approach to international IP law. In recent years, legal scholars and economists have increasingly examined intellectual property with attention to the consequences of IP regulation for the diffusion of new ideas, texts, and technologies. Contributions to this field have critically examined both the intended purpose of IP protections-to provide incentives for innovation-as well as their undesirable side effects-limiting freedom of expression, impeding follow-on innovation, diminishing market competition, and inflating the prices of consumer goods. This line of scholarship suggests that the rapid and still-unchecked expansion of IP claims over the past several decades is problematic, and that greater attention should be given to the properties of knowledge as a global public good, and the virtues of a minimalist approach to IP protection. ${ }^{7}$

From the human rights perspective, my argument is grounded in a little-studied provision of international public law. In 1948, Article 27 of the Universal Declaration of Human Rights affirmed that "[e]veryone has the right freely to participate in the cultural life of the community, to enjoy the arts and to share in scientific advancement and its benefits." In the same breath, the document also declared that "[e]veryone has the right to the protection of the moral and material interests resulting from any scientific, literary or artistic production of which he is the author." In the ensuing decades, the Universal Declaration's various rights provisions have been the subjects of extensive scholarship, jurisprudence, and policy debate. These processes of norm elaboration and development have served to translate

arguments may lay groundwork for claims that IP standards conflict with human rights obligations, elevate IP "users" to a more equal status with IP "rights-holders" and lead to pressure to establish international "maximum standards" for IP protection). See also Chapman, supra note 3; Yu, Reconceptualizing, supra note 2; Yu, Ten Common Questions, supra note 2.

7. This literature is discussed in depth at Part II.A. For further background, see Nagla Rizk \& Lea Shaver, Access to Knowledge: Economic, Global and Local Perspectives, in ACCESS to KNOWLEDGE IN EgYPT: NEW RESEARCH ON INTELleCtuAL Property, InNovation AND DEVElopment 1 (Nagla Rizk \& Lea Shaver eds., 2010), available at http://ssm.com/abstract $=1437611$; Lea Bishop Shaver, Defining and Measuring A2K: Blueprint for an Index of Access to Knowledge, 4 I/S J.L. \& POL'Y FOR INFO. SOC'Y 235 (2008); Lea Shaver, Intellectual Property, Innovation and Development: The Access to Knowledge Approach, in ACCESS TO KNOWLEDGE IN BRAZIL: NeW RESEARCH ON INTElleCtuAl PROPERTY, INNOVATION AND DEVELOPMENT 1 (Lea Shaver ed., 2010), available at http://ssrn.com/abstract $=1437274$.

8. Universal Declaration, supra note 1, at art. $27(1)$.

9. Id. at art. 27(2). 
originally vague right claims into detailed and specific legal norms defining the duties of States and other actors to respect, protect, and fulfill the asserted rights. Once these specific norms become widely accepted, they are then legally enforced-to varying degrees-by national and regional courts across the globe.

Over the last half-century, however, this process has largely neglected the right to science and culture. To date, little legal and academic work has been done to conceptualize this right and clarify what policy makers and courts must do to respect and protect it. In a recent volume on cultural rights, contributing human rights scholars concurred in describing the Article 27 right as particularly "undeveloped," 10 "poorly elaborated in terms of content and scope and often neglected in terms of implementation," the academic literature." ${ }^{\prime 2}$ In the assessment of human rights scholar

10. Audrey R. Chapman, Development of Indicators for Economic, Social and Cultural Rights: The Rights to Education, Participation in Cultural Life and Access to the Benefits of Science, in Human Rights in EduCation, SCIENCE and Culture: Legal Developments and Challenges 111, 132 (Yvonne Donders \& Vladimir Volodin eds., 2007) [hereinafter Chapman, Development of Indicators]. Chapman states:

To date . . there is little agreement as to how to interpret the content of the right to take part in cultural life as enumerated in Article 15(1)(a) of the ICESCR [which corresponds to Article 27 of the UDHR] or the resultant obligations on states parties. Cultural rights have been aptly characterized as "undeveloped."

Id.

11. Yvonne Donders, The Legal Framework of the Right to Take Part in Cultural Life, in HuMAN Rights in EDUCATION, ScIENCE AND Culture: Legal Developments and Challenges 231, 231 (Yvonne Donders \& Vladimir Volodin eds., 2007). Donders states:

[Cultural rights] have been poorly elaborated in terms of content and scope and often neglected in terms of implementation. One right which is undeniably a part of cultural rights is the right to take part in cultural life, which is laid down in Article 27 of the Universal Declaration of Human Rights (UDHR) and Article 15(1)(a) of the International Covenant on Economic, Social and Cultural Rights (ICESCR).... However, the normative content and scope of this right and state obligations in respect of it have been little studied.

Id.

12. William A. Schabas, Study of the Right to Enjoy the Benefits of Scientific and Technological Progress and Its Applications, in HUMAN RIGHTS IN Education, SCience AND Culture: Legal Developments and Challenges 273, 274 (Yvonne Donders \& Vladimir Volodin eds., 2007). Schabas states:

To borrow a concept from Hersch Lauterpacht, ... if economic, social and cultural rights lie at the vanishing point of international humanrights law, then the question of the right to enjoy the benefits of scientific and technological progress and its applications lies at the vanishing point of economic, social and cultural rights. Neither of the two provisions, Article 27(1) of the Universal Declaration and Article 15(1) of the covenant, is 
Audrey Chapman, "this right is so obscure and its interpretation so neglected that the overwhelming majority of human rights advocates, governments, and international human rights bodies appear to be oblivious to its existence." 13

What exactly did the framers of the Universal Declaration mean by Article 27's allusions to cultural participation and sharing in scientific progress? Why would they consider these goals important enough to include in a statement of fundamental human rights? How should we understand the concept and scope of these rights today? What should policy makers do to promote these rights? What are the biggest threats to these rights today, and how can human rights advocates and constitutional courts help defend against them? With so little basic conceptual clarity as to Article 27's purpose, scope, and implications, policy makers, jurists, and advocates are reluctant to invoke it.

With greater scholarly development, however, the right to science and culture can offer fertile ground for judicial and legislative experimentation to restore balance to international IP law. Although international human rights law receives relatively little attention in the United States, it carries great weight internationally. In Europe, Latin America, India, and many other jurisdictions, policy makers and the courts routinely look to international human rights norms to guide national decision-making. The World Trade Organization, too, accepts that trade treaties-including foundational IP instruments-must be interpreted in light of broader international legal norms, including human rights law.

With this end in mind, the present Article seeks to offer a theory of the right to science and culture-its purpose, scope, and implications-that is well-grounded both in international human rights doctrine, as well as recent scholarship on IP design from the legal, economic, and political science disciplines.

To be sure, Article 27 is not only about issues of intellectual property; the theory of the right to science and culture that I offer below has implications for many areas of law and policy, ranging from education to Internet governance. The conflicts between the right to science and culture and modern IP laws, however, are particularly stark. The problem has only become greater in recent decades, which have witnessed a sea change in international IP law, resulting in a

referenced in subsequent resolutions of the General Assembly. The issue has been barely addressed in the academic literature.

Id.

13. Chapman, Towards an Understanding, supra note 2, at 1. The context of this quotation is a focus on the scientific dimension of the right to science and culture. For Chapman's views on the cultural dimension of the right, see Chapman, Development of Indicators, supra note 10 . Chapman states: 
deeply imbalanced system that protects IP owneres too much, and the broader public interest too little. Yet the conflict with IP protection has received little attention in the existing literature on Article 27. ${ }^{14}$ For these reasons, the present Article emphasizes the interactions between IP and the right to science and culture.

Part I examines the historical context in which the right to science and culture was originally conceived and later translated into binding international law to offer insight the provision's original intended meaning(s). The purpose of this inquiry is not, in the true revisionist history tradition of Critical Legal Studies and Critical Racial Theory, to repudiate dominant accounts of legal history. ${ }^{15}$ Nor is my argument that the original intent-whatever that may be-must determine modern interpretations and applications of the law. Rather, my purpose is to develop a narrative that will render intelligible an interpretation that modern readers may find counterintuitive, in light of current dominant cultural and legal currents. I suggest that the essential purpose of Article 27-to promote universal access to science and culture-has been forgotten during the last several decades, even as international legal norms on intellectual property have evolved in ways that increasingly threaten this right.

Drawing on this historical perspective as well as more recent academic work in law and economics, Part II offers a theoretical framework for understanding the right to science and culture. I argue that Article 27 must be understood as a call for culture and science to be governed as global public goods, rather than as private property. Although this approach runs counter to modern conventional wisdom as reflected in current international IP law, it is consistent with the spirit of the human rights regime, as well as the recent call from legal and economic scholars to restore balance to international IP system, because it recognizes the special nature of knowledge as an economic resource that is increased, rather than diminished, when shared.

Part III of this Article explores what this reconstructed conception of the right to science and culture might mean in terms of concrete duties upon States parties to the human rights treaties. This Part first examines the extent the right to science and culture imposes actual legal obligations on governments. Next, this Part suggests concrete steps that States parties must take to ensure that their domestic IP regimes serve to respect, protect, and fulfill the right to science and culture. Part III concludes by examining the implications of this understanding of the right to science and culture for international IP law, and the challenges

14. See infra note 16 and accompanying text.

15. See, e.g., Richard Delgado \& Jean Stefancic, Critical Racial THEORY: AN INTRODUCTION (2001). 
presented to jurists confronted with adjudicating claims of conflicts between specific IP protections and the human right to science and culture.

The interpretation of Article 27 that I advocate-founded on a unique inquiry into the historical context of the Universal Declaration's adoption, as well as widely accepted methods of human rights treaty interpretation-is fundamentally at odds with the maximalist approach to IP protection that has dominated the World Trade Organization (WTO) and the World Intellectual Property Organization (WIPO) during the past few decades. In this way my theory of the right to science and culture departs significantly from the most sophisticated competing elaboration. Elsa Stamatopoulou's leading work treats the relationship of Article 27 to intellectual property as one primarily of non-discrimination, particularly vis-à-vis indigenous communities seeking ownership rights in traditional knowledge. ${ }^{16}$ This is typical of much other work in the field. Scholarship in this area does not yet sufficiently address what I argue is the larger problem: a fundamental conflict between the ever-upward expansion of IP protection, and the human right of access to science and culture.

Reconciliation, however, is possible. In this respect, I suggest that a restored understanding of the right to science and culture can provide much needed support to a movement already underway to rebalance international IP law. ${ }^{17}$ This movement's success depends on many factors, but one is the ability to articulate the competing values opposing IP protectionism as something on a higher level than the mere desire of developing countries to renegotiate more favorable terms of trade. ${ }^{18}$

16. Elsa Stamatopoulou, Cultural Rights in International law:

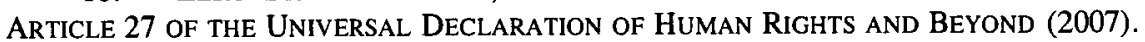
Stamatopoulou's work treats the topic of intellectual property at some length, but only in the context of ensuring that IP protection is expansive enough to include traditional knowledge ownership by indigenous peoples, and ensure that such knowledge is not wrongly patented by outsiders. The possibility that IP protection itself could constitute significant a barrier to the enjoyment of the Article 27 right, either by indigenous peoples or other groups, is not addressed in this work. See id. at 212-23.

17. See generally Amy Kapzcynski, The Access to Knowledge Mobilization and the New Politics of Intellectual Property, 117 YALE L.J. 804 (2008) (examining the emergence of a global social movement under the umbrella of "access to knowledge" through the lens of frame mobilization theory, and its implications for IP law and politics). For greater detail on the role of legal scholars within this movement, see Symposium, Cultural Environmentalism @ 10, LAw \& CONTEMP. PROBS., Spring 2007, and especially Lawrence Lessig, Foreword, LAw \& ConTEMP. ProbS., Spring 2007, at $1,1-2$.

18. For greater analysis of frame mobilization theory as it applies to the access to knowledge movement, see Kapzcynski, supra note 17. 
Reclaiming the right to science and culture offers a promising new opening for these efforts to make headway. On a political level, the right to science and culture framework reframes calls for greater access to knowledge no longer as a plea for charity toward developing countries, but rather as a demand for greater respect for the fundamental rights of all people. On a legal level, because of the copriority of international human rights commitments with trade ones, the right to science and culture can also offer a valid opening to modify an otherwise firmly entrenched international IP regime.

Uniquely, arguments based on the right to science and culture offer the prospect not only for special exceptions in the areas of health, food, or education, but for a more pervasive shift in the international IP ecosystem. Such systemic reforms ultimately offer potential for a greater impact for innovation and access in all areas of creativity and technology. In Helfer's terminology, whereas critiquing IP from the perspective of the right to health or food may constitute an "evolutionary" challenge to the international IP regime, the right to science and culture offers grounding for a "revolutionary" challenge. ${ }^{19}$

Scholarly work on this topic is particularly timely as the prospects for reviving the right to science and culture now stand at an important crossroads. The United Nations Committee on Economic, Social and Cultural Rights already in 2006 issued definitive guidance on what I term the "protection element" of the right, ${ }^{20}$ in the form of a General Comment. $^{21}$ The Committee chose, however, to reserve interpretation of what I call the "access element" for later. ${ }^{22}$ This decision should be understood as reflecting the Committee's judgment that the state of scholarship on this aspect of the right is less well-developed.

19. See Laurence Helfer, Regime Shifting: The TRIPS Agreement and New Dynamics of International Intellectual Property Lawmaking, 29 YALE J. INT'L. L. 1, 14-15 (2004).

20. The protection element refers to language about the moral and material interests of creators at Article 27(2) of the Universal Declaration, Article 15(1)(c) of the ICESCR, and Article XIII of the American Declaration. Universal Declaration, supra note 1, at art. 27(2); ICESCR, supra note 5, at art. 15(1)(c); American Declaration, supra note 5 , at art. XIII.

21. ECOSOC, Comm. on Econ., Soc. \& Cultural Rights, General Comment No. 17: The Right of Everyone to Benefit from the Protection of Moral and Material Interests Resulting from Any Scientific, Literary or Artistic Production of Which He or She is the Author, 35th Sess., U.N. Doc. E/C.12/GC/17 (Jan. 12, 2006) [hereinafter General Comment No. 17].

22. The access element refers to language about cultural participation and scientific benefit sharing, found at Article 27(1) of the Universal Declaration, Article 15(1)(a)-(b) of the ICESCR, and Article XIII of the American Declaration. Universal Declaration, supra note 1, at art. 27(1); ICESCR, supra note 5, at art. 15.1(a)-(b); American Declaration, supra note 5, at art. XIII. 
Efforts to develop General Comments on "the right to take part in cultural life" as well as "the right to enjoy the benefits of scientific progress and its applications" are, however, already in progress. ${ }^{23}$ These interpretative guidelines will constitute instructive or binding precedent for a number of national and international legal fora.$^{24}$ As such, they will have important consequences for later efforts to utilize human rights law to promote access to educational materials, access to medicines, and Internet freedom. If the Comments enshrine too narrow an understanding of the right to science and culture, or tip-toe around the conflict between the right and IP protection, the opportunity to use human rights norms to check the expansion of international IP law may be set back significantly. With care, however, the Committee's efforts may play a crucial facilitating role in rebalancing the international IP regime, to the benefit of human rights worldwide. ${ }^{25}$

\section{ARTICLE 27 IN HistoriCAL PERSPECTIVE}

Given the current dominance of the rhetorical frame of "IP rights," it should not be surprising that some would read Article 27(2) as enshrining a human right to intellectual property protection. The provision's call for "the protection of the moral and material interests resulting from any scientific, literary or artistic production" easily evokes for modern readers the IP framework that we have recently come to take so very much for granted. ${ }^{26}$

At the time the Universal Declaration of Human Rights was proposed and adopted in the late 1940s, however, the international treatment of intellectual property was significantly different from today.

23. The Committee has stated its intention to elaborate three General Comments, corresponding respectively to Article 15(1)(a), (b), and (c). General Comment No. 17, supra note 21 , at 2-3.

24. See infra notes 223-239 and accompanying text.

25. The Committee's guidance on scientific benefit sharing is still in progress. Its guidance on cultural participation was recently completed. ECOSOC, Comm. on Econ., Soc. \& Cultural Rights, General Comment No. 21: Right of Everyone to Take Part in Cultural Life (art 15, para. 1 (a), of the International Covenant on Economic, Social and Cultural Rights), U.N. Doc. E/C.12/GC/21 (Nov. 20, 2009) [hereinafter General Comment No. 21].

26. Universal Declaration, supra note 1. Perhaps because the protection element of Article 27 sounds more familiar to the modern ear, there has also been more work done on this secondary aspect of the right to science and culture. So far the "access" element has been comparatively neglected, although the inclusion of the two provisions side-by-side suggests that they were meant to be understood as interrelated. Indeed, as this Article suggests, there are historical and conceptual reasons to understand the "protection" element as secondary in importance to the "access" element. 
Indeed, the term "intellectual property" was not yet in common use. ${ }^{27}$ An accurate understanding of Article 27's intent and spirit requires an appreciation of this historical context as it relates to both access to and protection of cultural works and scientific discoveries.

Between 1948-when the Universal Declaration of Human Rights was enacted-and today, international IP law has undergone a sea change. Until quite recently, most developing nations either offered no recognition of patents or practiced sweeping rejections of patent applications in strategic sectors such as health and agriculture. ${ }^{28}$ International IP policy making in the 1970s and 1980s was dominated by efforts of developing countries to reduce IP protection and substitute international rules promoting competition and technology transfer. ${ }^{29}$ Even in the U.S., the scope and duration of IP protection were subject to significant limits in law and practice, compared to today.

Beginning in the late 1970s, however, national policy making in the United States and certain European countries began to reflect increasing support for a more maximalist approach to intellectual property protection. ${ }^{30}$ Domestically, this shift reflected the increasing strength of conservative political ideologies, which emphasized protection of private property as a fundamental right of particular importance. $^{31}$ The new enthusiasm for intellectual property found

27. Mark A. Lemley, Property, Intellectual Property, and Free Riding, 83 TEX. L. Rev. 1031, 1033 n.4 (2005).

28. During the 1960s and 1970s, when many Asian and African countries were first gaining independence, there was a broad movement of IP skepticism among developing nations, including those with longer traditions of independence. During this time, many developing countries scaled back their IP protections, particularly in strategic sectors for development. Kamal MalHotra ET AL., MAKING Global TRADE WORK FOR PEOPLE 204 (2003). See also Helfer, supra note 19, at 67-68.

29. Susan K. Sell, Power and IDEAS: North-South Politics of INTELLECTUAL PROPERTY AND ANTITRUST 107-10 (1998) [hereinafter SELL, POWER AND IDEAS].

30. William M. Landes \& Richard A. Posner, The Economic Structure of Intellectual Property Law 2 (2003); Adam B. Jaffe, The U.S. Patent System in Transition: Policy Innovation and the Innovation Process, 29 RES. POL'y 531, 531 (2000).

31. The conservative enthusiasm for intellectual property protection underestimated the differences between traditional property and IP. The concept of "intellectual property," a term first popularized in the 1960s, elides crucial differences between real (physical) property and ideas, the latter of which is infinitely shareable-a difference with important economic consequences. Exclusive rights in real property are necessary to allocate scarce goods, prevent exhaustion of limited resources, and ensure returns on investments. Exclusive rights in IP are not necessary to achieve these ends, and may in fact be counterproductive both to the conservatives' end goals of promoting economic growth and social liberty, because it unnecessarily limiting competition and the free use of valuable assets. 
expression in a number of domestic reforms increasing IP protection during the Reagan era. ${ }^{32}$

Beginning in the $1980 \mathrm{~s}$, at the behest of their IP industries, the U.S., EU, and Japan pushed for even higher IP protections through international treaties. ${ }^{33}$ Today all 153 members of the World Trade Organization must adhere to the common standards of IP protection espoused in the 1994 Agreement on Trade-Related Aspects of Intellectual Property Rights (TRIPS). ${ }^{34}$ These framework documents of international IP law promote what has been referred to as an "IPmaximalist" approach to innovation policy, in that they set required minimum levels of IP protection, but specify no upper limits; they set floors, but not ceilings. ${ }^{35}$ The effect is that each new multilateral or bilateral treaty operates to "ratchet up" levels of IP protection, promoting a unidirectional trend toward ever-higher levels of protection.

Alongside this decades-long policy shift has been a rising political discourse framing intellectual property protection as a fundamental right. Today, the language of "rights" dominates public as well as scholarly discourse on patents, copyrights, and trademarks. ${ }^{36}$ Various United Nations human rights bodies have recently been at pains to stress that Article 27 of the Universal Declaration does not recognize intellectual property as a human right. ${ }^{37}$ This is as it should be. Human rights law recognizes those entitlements that are inherent in the dignity of the human person and can never be surrendered. In contrast, patent

32. Landes and Posner identify the trend toward greater protection of intellectual property as beginning with the Copyright Act of 1976 and the creation of the U.S. Court of Appeals for the Federal Circuit in 1982, and accelerating in the 1990s with the Visual Artists Rights Act, the Architectural Works Protection Act, the Sonny Bono Act, and the Digital Millenium Copyright Act, among others. LANDES \& POSNER, supra note 30, at 406. To this list, Jaffe adds the Bayh-Dole Act of 1980 , which encouraged publicly supported universities to patent and exclusively license their discoveries. Jaffe, supra note 30, at 534-35.

33. See generally Susan Sell, Private Power, Public Law: The Globalization of Intellectual Property Rights (2003); Sell, Power and Ideas, supra note 29, at 137.

34. Agreement on Trade-Related Aspects of Intellectual Property Rights (TRIPS), April 15, 1994, Marrakesh Agreement Establishing the World Trade Organization, Annex 1C, 1869 U.N.T.S. 299 [hereinafter TRIPS].

35. J.H. Reichman, Universal Minimum Standards of Intellectual Property Protection Under the TRIPS Component of the WTO Agreement, 29 INT'L LAW. 345, 345 (1995).

36. A recent Web search revealed over 8 million results for the phrase "intellectual property rights." Google search for the term "intellectual property rights" (with quotation marks to ensure a match with the exact phrase) performed on March 1, 2010 returned "about $6,810,000$ " results.

37. General Comment No. 17, supra note 21, at 2. 
and copyright claims are time-limited and alienable, may be bought or sold, and may be possessed by corporations as well as individuals. To underscore the original understanding of these legal monopolies on knowledge as but a temporary license established for public benefit, it may be preferable to speak of "IP privileges" rather than "IP rights." Throughout this Article, I use the more neutral term "IP protections" to avoid confusion.

If not intended to recognize a human right to intellectual property, what was the original purpose of Article 27? I suggest that the answer to this question becomes clearer when we examine the historical context in which the right was initially solemnized by the international community. This historical context, I suggest, indicates that the framers were primarily concerned with ensuring universal access to the fruits of science and technology, as well as to the realm of cultural and artistic life, broadly understood.

On December 10, 1948, as one of its first official acts, the UN General Assembly adopted the Universal Declaration of Human Rights. ${ }^{38}$ This milestone, however, was part of a much broader process. Throughout the early 1940s, a wide range of voices-including heads of state, civil society organizations, and even the Pope-had pushed strongly for an "international bill of rights." ${ }^{39}$ By the time the United Nations was first formed in 1945, a number of detailed proposed drafts were already in circulation. ${ }^{40}$

Throughout the process of debate and adoption of what would eventually become the Universal Declaration, American leadership played a key role. This is true in both the narrow and broad senses of

38. Universal Declaration, supra note 1.

39. Johannes Morsink, The Universal Declaration of Human Rights: ORIGINS, DRAFTING AND INTENT 1 (1999).

40. The most influential of these were prepared by members of the American Law Institute (ALI) and the Inter-American Juridical Committee. Id. at 6. The ALI as an institution was and is very much grounded in the U.S. legal tradition, being most famous for its work on the Restatements of Law. Although all members of the working group were U.S. residents, they endeavored to reflect a range of culturally specific philosophical traditions in their work. Michael Traynor, The Statement of Essential Human Rights-A Groundbreaking Venture, Part I, ALI REP., Winter 2007, at 1, available at http://www.ali.org/_news/reporter/winter2007/01-President.html; William Draper Lewis, The Statement of Essential Human Rights by Representatives of the Principal Cultures of the World, 89 Proc. AM. PHIL. Soc'y 489 (1945). The InterAmerican Juridical Committee is an arm of the Organization of American States, established in 1906. See Comité Jurídico Interamericano, Breve historia del Comité Jurídico Interamericano [Brief History of the Inter-American Juridical Committee], http://www.oas.org/cji/nota_centenario_historia_cji.htm (last visited Feb. 5, 2010). During the 1930s, it began work on restatements of international law, similar to the work being done domestically by the ALI. See id. 
the adjective: referring either to the United States of America, or to the American Hemisphere.

In the narrow sense, U.S. leadership by President and First Lady Roosevelt was essential to the creation of the United Nations and the UN Charter's emphasis on human rights. The idea of the Universal Declaration is often traced to FDR's 1941 "Four Freedoms" speech. ${ }^{41}$ A committee of the American Legal Institute (ALI) began work on a highly influential draft in the early $1940 \mathrm{~s} .{ }^{42}$ After FDR's death in 1945, Eleanor Roosevelt became the public face of the effort and chaired the committee charged by the United Nations to draft the Declaration in 1947 and 1948.

In the broader sense, contributions by Canadian and Latin American players also played a crucial role. Credit for most of the drafting work must be given to Canadian legal scholar John P. Humphrey, who drew heavily on the work of the Inter-American Juridical Committee. ${ }^{43}$ The nations of Latin America-whose constitutions had long followed the U.S. example by incorporating bills of rights-were among the most enthusiastic supporters of the endeavor. Indeed, the Organization of American States reached agreement on its American Declaration of the Rights and Duties of $\mathrm{Man}^{44}$ about eight months prior to the UN General Assembly's adoption of the Universal Declaration. ${ }^{45}$

Just as the U.S. Bill of Rights reflects the experiences and thinking of the founding generation, the Universal Declaration is strongly shaped by the New Deal and World War II. The project is widely recognized as a reaction against Fascism and the Holocaust. Equally important, Johannes Morsink argues, is the final document's rejection of Communism's embrace of statism in favor of social democratic principles. ${ }^{46}$ To understand the impulse of the right to science and culture, then, it is helpful to look to the broad cultural and political shifts experienced both before and immediately after World War II.

41. See, e.g., CASS R. SunsteIN, THE SECOND BILl of Rights: FDR's UNFINISHED REVOLUTION AND WHY We NEED IT MORE THAN EVER 2 (2004).

42. See MORSINK, supra note 39 , at 6 .

43. Id.

44. American Declaration, supra note 5.

45. The American Declaration was adopted as Resolution XXX of the Final Act of the Ninth International Conference of American States, which assembled on March 30, 1948. Charles G. Fenwick, The Ninth International Conference of American States, 42 AM. J. INT'L L. 553, 553, 562 (1948). The Universal Declaration was adopted on December 10,1948. Universal Declaration, supra note 1. The content and format of the two instruments are substantially similar.

46. See MoRsINK, supra note 39 , at 157. 
To be clear, my argument is not that the right to science and culture must be interpreted in a certain way today merely because that is how the framers understood it. Arguments from originalism have a very different valence in international human rights law as opposed to U.S. constitutional debates. Arguably, it is easier to accurately infer the original intent of the Universal Declaration than of the U.S. Constitution, if only because the latter process lies within living memory. Nevertheless, international human rights law does not accord the authoritative status to original understandings that some constitutional scholars and jurists have endorsed. Rather, there is an explicit understanding that the content of rights should be allowed to grow over time, reflecting historical circumstances and popular demands. Grow, but not shrink. In the same way that TRIPS seeks to set a minimum floor for intellectual property protections while encouraging upward movement over time, the international bill of rights establishes a minimum floor for human rights. While expansion is welcome, any "rolling back" is considered illegitimate.

The right to science and culture may pose a unique example, however, of an instance where historical shifts in our understanding of the right have been to the detriment of the individual-narrowing, rather than expanding, our concept of the right. In such a context, I suggest that originalist inquiries may offer an essential methodology to correct our modern biases. The original intent thus uncovered need not bind modern interpretations and applications of the right. It should, however, open our eyes to more expansive readings of the text than were previously considered possible, and throw into clear focus exactly what would be lost by limiting ourselves to the modern one.

In short, my effort is to destabilize what many today take to be the plain meaning of the Article 27 text as protecting "the right to intellectual property." This was not, the following material will demonstrate, the understanding that the framers had of their endeavor. In fact, the purpose of the right to science and culture was quite different and very much in conflict with modern intellectual property law. In this way, my historical work might be best conceived within Bruce Ackerman's concept of "constitutional moments" as points of important, collective normative commitment intricately shaped by the historical experiences and needs of the time. ${ }^{47}$ For international human rights law, the post-WWII period is indisputably the most important of these moments. A closer examination of this period has much to tell us about the value and purpose of recognizing a universal human right to science and culture.

47. See generally 2 Bruce ACKerman, We the People: Transformations (1998). 


\section{A. Expanding Access to Science and Culture}

To Americans in the 1930s and 1940s, the pace of scientific innovation was breathtaking. Public investments in science stimulated by the New Deal and the war effort had revealed the power of technological discovery to raise living standards and solve common problems. New technologies, it was realized, could improve the lives of millions, if only made widely accessible.

Access, however, was not a foregone conclusion. The market for technological goods might be plagued by monopolies as firms sought to crowd out competitors through strategic patenting. Scientific research of crucial social importance might be neglected by the market in the absence of public or charitable spending. During this era, however, several major historical events demonstrated the potential of collaborative efforts to overcome such barriers.

For example, by the 1930s, the technology of electricity had been well understood for at least a half-century. The possibility of a light bulb had first been discovered in $1709,,^{48}$ and the first commercially viable electric light was built in $1876 .{ }^{49}$ In 1881 , London's Savoy Theatre installed electric lighting, an event then of sufficient technological novelty to warrant comment in the scientific journal Nature. ${ }^{50}$ In 1886 , electric lighting was used to dramatic effect in the U.S., permanently illuminating the Statue of Liberty; in the 1890s, Broadway became known as "The Great White Way" for the nighttime illumination cast by its many electric advertisements. ${ }^{51}$

Yet for decades, high prices prevented the technology's transformation from public spectacle to domestic utility. Ultimately, changes in law and policy were required to drive the transformation. As historian David Nye writes,

[t]hough it might be tempting to . . . view the electrification of the United States as a natural result of a freely operating marketplace, such was hardly the case. In no society was electrification a "natural" or "neutral" process; everywhere it

48. Records of experiments with a working electric light bulb were first published by Royal Academy researcher Francis Hauksbee in 1709. PARK BENJAMIN, THE INTELLECTUAL RISE IN ELECTRICITY: A HISTORY 457 (1895).

49. AlFred RITTER VON URBANITZy, Electricity IN THE SERVICE OF MAN: A Popular and Practical Treatise on the Applications of Electricity IN Modern

LIFE 511 (R. Wormell trans., 1886) (1889).

50. The Electric Light at the Savoy Theatre, 27 NATURE 418 (1883); The Savoy Theatre, Times (London), Oct. 3, 1881, at 7.

51. David E. Nye, Electrifying America: Social Meanings of a New TeChNOLOGY, 1880-1940, at 32, 50 (1992). 
was shaped by complex social, political, technical and ideological interactions. ${ }^{52}$

Scandinavia, Germany, and Holland had all achieved 90 percent home electrification by $1930 .^{53}$ New Zealand and England also achieved nearly universal service around the same time.$^{54}$ On the eve of the Great Depression, however, few American households were electrified.

That changed forever during the 1930s and 1940s, propelled in no small part by a significant popular movement demanding broader access to electric power through the creation of public utility companies. Illustrating the politically "charged" environment, the mayor of Huntington, Indiana went to jail in 1935 for defying a court order forbidding the operation of a municipal utility. ${ }^{55}$ Public demand for access won out, resulting in important national policy shifts. In 1934, President Roosevelt created the National Power Policy Committee. ${ }^{56} \mathrm{~A}$ 1935 act of Congress gave new regulatory powers to the SEC and the Federal Power Commission. ${ }^{57}$ New Deal infrastructure investments greatly expanded electric generation capacity. A number of city and state governments also adopted measures to promote the affordability of electric power, particularly for non-urban residents, although these efforts were very much of a patchwork nature. ${ }^{58}$

If electricity reform demonstrated the power of non-market efforts to diffuse existing technologies, the quest for a polio vaccine demonstrated their power to discover new ones. As Jane S. Smith recounts, the National Foundation for Infantile Paralysis had launched its first March of Dimes in $1938 . .^{59}$ In 1945 , the organization raised $\$ 20$

52. Id. at $138-39$.

53. A variety of approaches were deployed to achieve this goal. In Scandinavia, utilities were typically state-owned. In Germany, a standardized national market was achieved through the grant of a monopoly to a single company. Interestingly, the German company was required to compensate the public for its exercise of the monopoly privilege. In contrast, the U.S. at this stage was still characterized by a patchwork of isolated private companies operating with incompatible technological standards. Id. at 140.

54. Id. at 387-88. In England, the goal was achieved by nationalizing a previously localized and private system of electricity generation and distribution. Id. at 387.

55. Id. at 349. President Roosevelt fared better when the Supreme Court upheld the constitutionality of the Tennessee Valley Authority's sale of publicly generated electric power. Ashwander v. Tenn. Valley Auth., 297 U.S. 288, 335-37 (1936).

56. NYE, supra note 51 , at 350.

57. Id.

58. See id. at 388.

59. Jane S. Smith, Patenting the Sun: Polio and the Salk Vaccine 73 (1990). 
million to fund basic research and provide care to polio victims. ${ }^{60}$ As the charity's scientific investments translated into visible progress toward a vaccine, government entities also began to show interest in expanded public support for research. The National Institutes of Health began to issue their first grants to outside researchers in $1945 .{ }^{61}$ In 1946 , Pittsburgh began to invest in its local university as a site of medical-science research; both Dr. Spock and Jonas Salk would lead importance research programs there. ${ }^{62}$ The success of Salk's vaccine research had not yet been proven when the Universal Declaration was signed. By 1949, however, the National Foundation had correctly predicted that a safe, effective vaccine was only a few years away. ${ }^{63}$

The ultimate breakthrough was the product of an entire generation's hopes and sacrifices. Millions had given money to the campaign, and the volunteer networks-of professionals, public figures, mothers and even children-were deep. When field testing was announced, the director of the National Foundation's volunteer efforts explained the unprecedented support of mothers for the effort: "They thought it was their vaccine! They had done so much volunteer work, each one of them felt she was a majority stockholder!" Foundation's lawyers concurred, determining that since Salk's vaccine was not derived from any truly new processes or materials, it could not-under the standards of the day-be patented, but lay in the public domain. ${ }^{65}$ Salk worried, nonetheless, that the company preferred by the National Foundation to commercially produce the vaccine sought to wrap it in an unnecessary, patented production process ${ }^{66} \mathrm{He}$ insisted the Foundation eschew exclusive provider deals; ultimately six companies signed on to produce Salk's vaccine. ${ }^{67}$

60. Id. at 78,82 .

61. See id. at 80,99 .

62. Id. at $101-02$.

63. Id. at 99 .

64. Id. at 87 .

65. Id. at 220. The vaccine's development did rely on discoveries of other scientists that probably could have been patented, notably a new process for reproducing poliovirus more efficiently through tissue cultures, discovered by John Enders, Tom Weller, and Frederick C. Robbins in 1949, also working with partial support of the National Foundation. Id. at 126-27, 335. The scientists' reward was a Nobel Prize in 1954. Id. at 335.

66. Id. at 220.

67. Id. at 220-21. This figure is for production of vaccine for the national field trials alone. The National Foundation covered the companies' investments during the field trial through an at-cost purchasing deal; the companies that participated on these terms gained a competitive advantage of lead-time against additional pharmaceutical firms that entered the polio vaccine market later. Id. at 221-22. 
The popular movements to electrify America and fund the discovery of a polio vaccine demonstrated the potential of efforts deliberately aimed at harnessing scientific and technological discovery for the benefit of all. The Roosevelt administration explicitly called on science to solve pressing human challenges and serve the nation's collective war effort. After the war in particular, a new enthusiasm emerged within the scientific and academic communities to put their efforts to serve humanity.

A similar vision emerged in the same era for the arts and education. Here, the traditional emphasis on "high culture" and higher education as domains of the social elite was called into question. Art was newly democratized, promising a role for ordinary people not only as bystanders, but also as participants. Federal support was provided for public libraries and public theater, as well as vast projects to document folk culture. A 1946 United States Department of Agriculture publication on rural handicrafts captured the new democratic sensibility:

We now recognize that the aesthetic experience can be as deep and as genuine to the one who uses soil, or wood, or grass to shape his best concept as to one who does the same with paint or marble; and that the spade, the ax, and the scythe are as much tools for artistic expression as are the brush and the chisel. ${ }^{68}$

Interest in folklore had begun to surge in the 1920s, as demonstrated by the widespread embrace of jazz music and the establishment of the Archive of American Folk Song at the Library of Congress in 1928. ${ }^{69}$ The innovation of the 1930s and 1940s was to view folk culture as a matter of sufficient worth to justify public funding support and public policy formation. ${ }^{70}$ According to Peggy Bulger, national interest in folklore was not a New Deal invention, but predated

68. Allen Eaton \& LuCinda Crile, Rural Handicrafts in the United STATES 8 (1946).

69. See also Lauren Coats \& Nihad M. Farooq, Regionalism in the Era of the New Deal, in A Companion to the Regional Literatures of America 74, 75 (Charles L. Crow ed., 2003) (identifying a rising scholarly interest in folklore and regionalism in the decade prior to the New Deal).

70. See Juretta Jordan Heckscher \& Susan Garfinkle, Folklore and Folklife, in Material Culture in America: Understanding Everyday Life, 194, 195-96 (Helen Sheumaker \& Shirley Teresa Wajada eds., 2008) ("New Deal programs anticipated what has become since the 1960s the most important development in the discipline: the rise of "public folklore;" that is, the documentation, study, support, and presentation of folk culture in and through public institutions."). 
Roosevelt's efforts and was supported from all political wings. ${ }^{71}$ This contemporary movement firmly stamped the New Deal's ambitious projects in music, arts, theater, and literature. ${ }^{72}$ A growing interest in oral history gained support from the New Deal effort as well, including large-scale projects to document the memories of ex-slaves. ${ }^{73}$

The new democratic impulse impacted education policy as well. With the GI Bill of 1944, American university life was forever transformed. Higher education enrollment climbed 75 percent between 1940 and $1948 .^{74}$ Because veterans' tuition was paid by the federal government, college attendance was opened up to qualified students from the middle and lower classes in significant numbers for the first time. ${ }^{75}$

Other human rights scholars have suggested that Article 27's reference to cultural life was, at its framing, understood narrowly to refer to elite culture and the fine arts. The experience of the United States during the 1920s-1940s, at least, casts doubt upon this theory. A broader understanding of cultural and artistic merit had already become firmly established before World War II. Although an international survey of evolving concepts of art and culture is beyond the scope of this Article, it seems likely that this shift had corollaries in other countries as well. Why should the democratic spirit expressed by the New Deal in the U.S., by social democracy in Europe and Latin America, and by anti-colonial movements in Asia not also find expression in contemporary understandings of what was valued in cultural life?

What can be stated with certainly is that, at the signing of the Universal Declaration, the United Nations had come to envision the sharing of scientific and cultural knowledge as something that could unite an international community-a common task that would contribute to cross-cultural understanding and yield a more secure world than that which characterized the 1930s and early 1940s. This vision found expression in the United Nations Educational, Scientific and Cultural Organization (UNESCO), established during the drafting of the Universal Declaration.

71. Peggy A. Bulger, New Deal and Folk Culture, in AMERICAN FolkLORE: AN ENCYCLOPEDIA 507, 507 (Jan Harold Brunvand ed., 1996).

72. Id. at 507-09.

73. Ian R. Tyrrell, Historians in Public: The Practice of american HISTORY, 1890-1970, at 179-80 (2005).

74. Glenn C. Altschuler \& Stuart M. Blumin, The Gi Bill: A New Deal FOR VETERANS 92 (2009).

75. It would be decades longer, of course, before legal reform and the broadening of federal financial aid made higher education accessible to the majority of Americans, particularly women and minorities. 
As a colleague and I have previously suggested, the establishment of UNESCO is particularly indicative of what the Declaration's framers had in mind by the right to science and culture. ${ }^{76}$ The 1945 UNESCO Constitution established the Organization with the mission "to contribute to peace and security by promoting collaboration among the nations through education, science and culture."77 The constitution further declared "the wide diffusion of culture" to be "a sacred duty which all the nations must fulfil in a spirit of mutual assistance and concern." 78 Toward that end, the international community invested it with a mission to "maintain, increase and diffuse knowledge" through efforts of conservation, international cooperation, and exchange. ${ }^{79}$ Note that as used by UNESCO and the Declaration, the term "culture"

76. Lea Shaver \& Caterina Sganga, The Right to Take Part in Cultural Life: On Copyright and Human Rights, 27 WIS. INT'L L.J. 637, 642 \& n.19 (2010). See also Yvonne Donders, Cultural Life in the Context of Human Rights, 3, Background Paper Submitted to the Comm. on Econ., Soc. \& Cultural Rights, U.N. Doc. E/C.12/40/13 (May 9, 2008).

77. Constitution of the United Nations Educational, Scientific and Cultural Organization, art. 1, sec. 1, adopted in London Nov. 16, 1945, 4 U.N.T.S. 275 [hereinafter UNESCO Constitution]. Article 1, section 1 states:

The purpose of the Organization is to contribute to peace and security by promoting collaboration among the nations through education, science and culture in order to further universal respect for justice, for the rule of law and for the human rights and fundamental freedoms which are affirmed for the peoples of the world, without distinction of race, sex, language or religion, by the Charter of the United Nations.

Id.

78. The Preamble of the UNESCO Constitution states:

The Governments of the States parties to this Constitution on behalf of their peoples declare, ... that the wide diffusion of culture, and the education of humanity for justice and liberty and peace are indispensable to the dignity of man and constitute a sacred duty which all the nations must fulfil in a spirit of mutual assistance and concern.

Id.

79. The UNESCO Constitution states:

To realize this purpose the Organization will ... maintain, increase and diffuse knowledge; by assuring the conservation and protection of the world's inheritance of books, works of art and monuments of history and science, and recommending to the nations concerned the necessary international conventions; by encouraging co-operation among the nations in all branches of intellectual activity, including the international exchange of persons active in the fields of education, science and culture and the exchange of publications, objects of artistic and scientific interest and other materials of information; by initiating methods of international co-operation calculated to give the people of all countries access to the printed and published materials produced by any of them.

Id. at art. 1, sec. 2(c). 
should be understood broadly to refer to both science and the arts. ${ }^{80}$ Indeed, the understanding that "culture" includes science and technology was so taken for granted at the time these documents were adopted, that the word "scientific" was added to UNESCO's title only at a late date. ${ }^{81}$

At first glance, scientific and cultural development may appear as an inevitable and natural phenomenon. At some point, a new technology or cultural work is introduced and soon, it seems, everyone has access to it. From this standpoint, the assertion of a right to science and culture would make little sense: what has the law to do with science and culture? The framers of the Universal Declaration of Human Rights and founders of UNESCO, however, saw things very differently. They observed that technological innovations did not inevitably make their way to the masses, even in the world's most advanced economies. They realized that access to essential determinants of quality of life-from electricity to vaccines to books and, yes, theater-was crucially shaped by law and policy. And so, from the very first draft of the proposed international bill of rights to the very last, they included language declaring access to science and culture not to be a privilege of the wealthy few, as in the past, but a right to be assured to all. ${ }^{82}$

As a statement of broad principles, of course, the Universal Declaration left open how this end was to be achieved. This question will be taken up in greater detail in Parts II and III of this Article.

80. The Declaration of the Principles of International Cultural Co-operation, proclaimed by the General Conference of the United Nations Educational, Scientific and Cultural Organization at its fourteenth session on November 4, 1966, defines "culture" broadly:

International cultural co-operation shall cover all aspects of intellectual and creative activities relating to education, science and culture. The aims of international cultural co-operation . . . shall be . . . To enable everyone to have access to knowledge, to enjoy the arts and literature of all peoples, to share in advances made in science in all parts of the world and in the resulting benefits, and to contribute to the enrichment of cultural life.

Declaration of the Principles of International Cultural Co-operation, arts. 3-4, United Nations Educational, Scientific and Cultural Organization, Records of the General Conference 86, 87-88, 14th Sess. (Paris 1966) [hereinafter Declaration of the Principles of International Cultural Co-operation].

81. Jerome H. Reichman et al., Access to Scientific and Technological Knowledge: UNESCO's Past, Present and Future Roles, in 1 STANDARD-SETTING IN UNESCO: NoRmative Action IN EduCation, Science and Culture 323, 323 (Abdulqawi A. Yusuf ed., 2007).

82. See supra notes 76-81 and accompanying text. 


\section{B. Protecting the Interests of Authors}

So far we have reviewed what the historical context of the 1930s and 1940s can tell us about the framers' vision for science and culture, with particular emphasis on the "access" element. But Article 27 also included a "protection" element. What light can the historical record shed on the meaning of this provision?

The first insight to be gained from the historical view is that this second element of the right to science and culture provoked significant controversy among the Declaration's framers. The "access" element of Article 27 was included in the earliest draft, ${ }^{83}$ and virtually no objections to its inclusion were ever raised during the extended process of international debate and ratification. ${ }^{84}$ The notion of protection for creators' interests, however, was introduced into the draft bill of rights later, initially rejected as inappropriate for inclusion in a human rights document and subject to protracted debate.

The push for protection of authorship was championed by René Cassin of the French delegation. ${ }^{85}$ His originally suggested text read: "The authors of all artistic, literary, scientific works and inventors shall retain, in addition to just remuneration for their labour, a moral right on their work and/or discovery which shall not disappear, even after such a work and/or discovery shall have become the common property of mankind. ${ }^{86}$ As finally adopted, however, the provision would refer

83. The original draft referred to "the right to participate in the cultural life of the community, to enjoy the arts and to share in the benefits of science." The Humphrey Draft, art. 44, reprinted in MARY ANn Glendon, A WORLD MADE NEw: ELEANOR RoOSEVElT AND THE UNIVERSAL DECLARATION OF HUMAN Rights app. I, at 274 (2001). For a detailed account of how the originally proposed language resulted in the final language, see Yu, Reconceptualizing, supra note 2, 1053-54.

84. The exception to the rule occurred at the first instance of review of Humphrey's draft. Morsink notes that the right to science and culture, contrary to many of the provisions included in the Universal Declaration, had at the time no precedents in national constitutions. It was suggested in the drafts of the Inter-American Juridical Committee, and Humphrey adopted it enthusiastically in the initial draft. MoRsinK, supra note 39 , at 217-18. In initial committee discussion, the Panamanian delegate proposed the Article be deleted as duplicative of others already included; nevertheless, the Article was accepted 3 to 1 with 2 abstentions. Id. at 32, 218. From this point forward, Morsink reports that debate over the "access" provision concerned only minor wording choices. Id. at 218-19. An account of the later drafting history of the related provision in the ICESCR in the 1950s affirms that no controversy as to the "access" provision was raised there either. ECOSOC, Comm. on Econ., Soc. \& Cultural Rights, Background Paper: Drafting History of the Article 15(1)(c) of the International Covenant on Economic, Social and Cultural Rights, If 19-20, 24th Sess., U.N. Doc. E/C.12/2000/15 (Nov. 27, 2000) (prepared by Maria Green).

85. MORSINK, supra note 39, at 29, 220-21.

86. MORSINK, supra note 39, at 220. 
only to authors, not to inventors. ${ }^{87}$ Moreover, as a right to just remuneration for all forms of work was separately provided for by Article $23(3),{ }^{88}$ the essential innovation of the proposal was to introduce into the document the concept of moral rights of authors. This proved to be a controversial point.

The Canadian scholar who produced the first draft of the Declaration, John Humphrey, declined Cassin's suggestion to include such language.$^{89} \mathrm{~A}$ formal French proposal to add a provision on moral rights was voted down at the First Session of the Drafting Committee, which met in June $1947 .^{90}$ Apparently, the French delegation then took its arguments behind the scenes to a different forum: the simultaneous

87. Universal Declaration, supra note 1, at art. 27(2) ("Everyone has the right to the protection of the moral and material interests resulting from any scientific, literary or artistic production of which he is the author."). This is true also of the later International Convention on Economic, Social and Cultural Rights, which speaks of the right of everyone to "benefit from the protection of the moral and material interests resulting from any scientific, literary or artistic production of which he is the author." ICESCR, supra note 5, at art. 15(1)(c). Invention is, however, included in the provision as it appears in the American Declaration. "Every person ... has the right to the protection of his moral and material interests as regards his inventions or any literary, scientific or artistic works of which he is the author." American Declaration, supra note 5, at art. XIII. The UN Committee on Economic, Social and Cultural Rights has arguably interpreted the provision to cover inventors by defining "scientific, literary or artistic production" extremely broadly to refer to "creations of the human mind ... such as scientific publications and innovations, including knowledge . ..." General Comment No. 17, supra note 21 II 9. Nevertheless, the committee took pains to emphasize in the next breath that such protection "need not necessarily reflect the level and means of protection found in present copyright, patent and other intellectual property regimes . . . ." Id. II 10.

88. Note that "just remuneration" is separately provided for at Article 23(3) of the Universal Declaration: "Everyone who works has the right to just and favourable remuneration ensuring for himself and his family an existence worthy of human dignity, and supplemented, if necessary, by other means of social protection." Universal Declaration, supra note 1, at art. 23(3).

89. Ironically, the push to recognize the moral rights of authorship may have found its greatest champion in a man who exhibited little respect for them in practice. Historian Johannes Morsink suggests that Cassin later inappropriately took credit as the primary drafter of the Declaration, credit that in fact should be due to John P. Humphrey:

Cassin clearly overstated his role when in a 1958 lecture he explained that he had been "charged by his colleagues to draft, upon my sole responsibility, a first rough draft" of the Declaration. Humphrey was right when he went public in his memoirs with something he had known all along, namely that "Cassin's new text reproduced my own in most of its essentials and style." Since so much of the Cassin rewrites came directly from the original Humphrey draft, it makes no sense to say that Cassin ever made an independent draft of the Declaration.

MORSINK, supra note 39 , at 8-9.

90. Id. at 7, 220. 
debates on the drafting of the American Declaration of the Rights and Duties of Man. ${ }^{91}$ Although the United States had opposed inclusion of a "protection" element in the Universal Declaration, Latin American votes led to its inclusion in the American Declaration, finalized in 1948. ${ }^{92}$ When the Third Session of committee meetings on the Universal Declaration resumed in May 1948, protection for the "moral and material interests" of authors had already been formally recognized as a human right in the regional instrument. ${ }^{93}$ Nevertheless, the Third Session again voted to exclude it from the Universal Declaration by a vote of six to five. ${ }^{94}$ A renewed proposal to add a "protection" element was approved 18-13 by the Third Committee, which met from September to December 1948, with leadership from the Cuban and Mexican delegations as well as the French, over the opposition of the United States, United Kingdom, and Australia. ${ }^{95}$

The strength of the opposition to this particular provision-with protracted arguments by many delegations seeking not only its modification, but rather its complete exclusion-appears to be unique in the history of the international bill of rights. ${ }^{96}$ Overall the drafting process inclined toward a broad elaboration of rights. While proposals for wording changes were frequently entertained, motions to strike a specific right from the document are almost without precedent. ${ }^{97}$ This is also true of the narrow margin on which the "protection" element was finally adopted for inclusion. More typically, proposals for changes were voted up or down with near unanimity or, at worst, abstentions. ${ }^{98}$

Moreover, opposition to the provision did not dissipate after the Declaration's signing. In the early 1950s, the United Nations took up the process of translating the Declaration's principles into a binding international convention. Here again, the "access" element was approved without controversy. ${ }^{99} \mathrm{~A}$ renewed effort emerged, however, to have the "protection" element omitted. Opponents of the moral and material interests provision were successful in winning its exclusion from drafts approved in 1951 and $1952 .{ }^{100}$ After significant debate, the

91. See American Declaration, supra note 5.

92. Id.

93. MORSINK, supra note 39, at 221.

94. Id.

95. Id. at 221-22.

96. For a detailed account of the arguments made for and against inclusion of the Article 27(2) provision and their sources, see id. at 219-22.

97. See generally MORSINK, supra note 39.

98. Id.

99. Green, supra note 84, at 91 19-20.

100. Id. at 99 21-32. 
provision was restored in a $1957 \mathrm{draft}^{101}$ The convention was ultimately adopted in 1966, including both the "access" and "protection" elements. ${ }^{102}$

The enduring controversy over the protection element reflects an underlying international disagreement about the underpinnings of copyright law. Within the common law tradition, the exclusive rights of authors to control publication of their works are considered solely in economic and utilitarian terms as providing incentives for creativity. ${ }^{103}$ Within the civil law tradition, the natural law concept of droit d'auteur recognizes additional, inalienable rights of authors grounded in the ethical conception of the creative product as an extension of the creator's personality. ${ }^{104}$ From the civil law perspective, then, authors' rights were grounded in the same basis as other human rights and should sensibly be included in the Declaration. From the common law perspective, a moral rights provision risked introducing a complex area of disagreement that more appropriately belonged to the realm of economic and trade law.

At the same time that the Universal Declaration and the American Declaration were being debated, indeed, the international community was at work on two competing copyright treaties. The Berne Convention was favored by Europe and its colonies and reflected a more protectionist approach. The Universal Copyright Convention was favored by the U.S., most of Latin America, and the Soviet bloc, and represented a more open one. Berne provided for copyright protection for a term comprising "the life of the author, and fifty years after his death." ${ }^{105}$ It also contained a provision on moral rights, providing that "[i]ndependently of the author's copyright . . . the author shall have the right ... to claim authorship of the work and to object to any

101. Id. at $1933-43$.

102. ICESCR, supra note 5 , at art. 15 .

103. See, e.g., U.S. CONST. art. $1, \S 8$, cl. 8 (stating that Congress shall have power "[t]o promote the Progress of Science and useful Arts by securing for limited Times to Authors and Inventors the exclusive Right to their respective Writings and Discoveries").

104. For a discussion of the philosophical bases of the two approaches, see Neil Netanel, Copyright Alienability Restrictions and the Enhancement of Author Autonomy: A Normative Evaluation, 24 RuTGERS L.J. 347 (1993).

105. An earlier version of the Berne Convention suggested this term while allowing for variation. Berne Convention for the Protection of Literary and Artistic Works, art. 7, Sept. 9, 1886, 123 L.N.T.S. 233, available at http://treaties.un.org/doc/Publication/UNTS/LON/Volume\%20123/v123.pdf (revised at Rome June 2, 1928) [hereinafter Rome Revision]. A 1948 revision required this term as a minimum, allowing only for upward variation. Berne Convention for the Protection of Literary and Artistic Works, art. 7, Sept. 9, 1886, 331 U.N.T.S. 217, available at http://treaties.un.org/doc/Publication/UNTS/Volume \%20331/volume-331-I-4757-

English.pdf (revised at Brussels June 26, 1948) [hereinafter Brussels Revision]. 
distortion, mutilation or other alteration thereof, or any other action in relation to the said work which would be prejudicial to his honour or reputation." ${ }^{106}$ In contrast, the Universal Copyright Convention allowed for more limited terms of protection as well as formal registration requirements rather than automatic protection of all works. ${ }^{107}$

Positions split largely along these lines, with civil law countries favoring inclusion of moral rights in the Universal Declaration and common law countries opposed. The French delegation served as the most consistent and passionate advocate at all stages of the debate. Reflecting the French cultural and Roman legal influence, most Latin American countries lined up in support. ${ }^{108}$ Within the U.S. delegation, both Roosevelt and Wilson objected that protection of authors belonged "to the domain of copyrights" rather than human rights. ${ }^{109}$ The U.K. delegation insisted that "copyright ... was not a basic human right" and objected to the inclusion of rights targeted at specific classes of people, rather than "principles that were valid for all men." ${ }^{110}$ Common law India joined the United States and the United Kingdom in opposition. $^{111}$

Normative disagreement over the existence of moral rights in authorship would be sufficient to account for the strength of the opposition to this particular provision. In addition, the notion of recognizing rights for a special class of citizens did not sit well with all delegates. The Universal Declaration of Human Rights was intended and designed to recognize rights "universally" held by "everyone." 112 A provision on "the rights of authors" as a special class would not fit within this frame. The compromise is noted in the somewhat linguistically awkward final formulation: "Everyone has the right to the

106. Brussels Revision, supra note 105 , at art. 6 bis. The corresponding language from 1928 is substantially identical. Rome Revision, supra note 105, at art. 6bis.

107. Universal Copyright Convention, Sept. 6, 1952, 6 T.I.A.S. 2731, 216 U.N.T.S. 132 (ratified by the U.S. Nov 5, 1954).

108. The vote to add in the "protection" element at the Third Committee prevailed 18-13, with 10 abstentions. Countries voting in favor included: Argentina, Belgium, Brazil, China, Colombia, Cuba, Dominican Republic, France, Greece, Honduras, Luxembourg, Mexico, the Netherlands, Panama, Peru, Poland, Uruguay and Venezuela. MorsinK, supra note 39, at 222.

109. Id. at 220 .

110. Id. at 221.

111. Id. at 220-21.

112. Universal Declaration, supra note 1. 
protection of the moral and material interests resulting from any scientific, literary or artistic production of which he is the author."113

A deeper structural tension, however, might also have stoked the controversy. Could a provision on "protection" of authorship be interpreted to be in tension with the provision on "access" to science and culture? Today, such a tension seems obvious, and it is common to hear calls for "balancing" respect for authors' rights (intended broadly to refer to copyright, not just moral rights) with the public's interest in access. ${ }^{114}$ No such objection was recorded, however, during the Declaration's debate and ratification. ${ }^{115}$

Looking beyond the drafting of the Declaration itself to the later process of drafting the conventions, Maria Green suggests that the framers were largely blind to this now-obvious conflict.

By raising both [access and protection] to the level of human rights, the drafters set up a tension that must be resolved if Article 15 is to be made effective. It is fascinating to note, however, that the distinguished men and women who gave us the ICESCR did not seem to deeply consider the difficult balance between public needs and private rights when it comes to intellectual property. ${ }^{116}$

I suggest, however, that the framers of Article 27 did not perceive a fundamental tension between its two elements because the state of copyright law at the time was markedly different from its condition today in ways that have important implications for the impact of copyright on public access. Today, there is a strong international norm in favor of automatic copyright protection without registration or renewal requirements, without limitation as to copyrightable subject matter, and for an essentially permanent term. ${ }^{117}$ In 1948 , however, copyright was applied in a much more limited way, and important rifts characterized the international field. Many nations required authors to formally register a work in order to receive protection, and recognized copyright benefits for much shorter terms. ${ }^{118}$ The historical context thus

113. Id. (emphasis added). The provision was thus adjusted to protect not the rights of a special class of authors, but the interests of everyone in authorship. See infra Part III (discussing the practical implications of this conceptual distinction).

114. See infra Part II.B-C.

115. See MoRsINK, supra note 39, at 217-22.

116. Green, supra note 84 , at $₫ 45$.

117. TRIPS, supra note 34, at Part II, Section 1 (Copyright and Related Rights).

118. For instance, U.S. copyright law through the 1960s imposed requirements of national registration and formal notice on the work; additionally protection was 
suggests that the "protection" element of the right should be understood as compatible with a wide variety of approaches to intellectual property.

Indeed, as human rights can only be possessed by individuals and may never be bought or sold, it would make little sense to think of intellectual property as a human right. For this reason if for no other, the UN committee charged with interpreting the right to science and culture has already taken pains to clarify that intellectual property itself is not a human right. Notably, the most important intellectual property treaty in force today incorporates all the copyright protections for publishers mandated by the Berne Convention but specifically excludes the very moral rights of authors recognized in the Universal Declaration. ${ }^{119}$ This illustrates well the disconnection between modern copyright and human rights. Indeed, the broad failure of copyright law, particularly as implemented in TRIPS, to truly protect the moral and material interests of authors has been criticized by creators' associations. ${ }^{120}$ Rather than enshrining a right to intellectual property, the "protection" element should be understood to refer only to the creator's right to obtain a decent standard of living from their work, and to preserve their moral rights of attribution and integrity. ${ }^{121}$

limited for works physically printed outside the United States. Melville B. Nimmer, Implications of the Prospective Revisions of the Berne Convention and United States Copyright Law, 19 STAN. L. REv. 499, 500-01 (1967). The standard term of protection was only 28 years, with an additional 28 years subject to active renewal. Id. at 500 .

119. TRIPS, supra note 34. Part II, Section 1 "Copyright and Related Rights," Article 9 "Relation to the Berne Convention" reads in relevant part:

1. Members [of the WTO] shall comply with Articles 1 through 21 of the Berne Convention (1971) and the Appendix thereto. However, Members shall not have rights or obligations under this Agreement in respect of the rights conferred under Article 6 bis of that Convention or of the rights derived therefrom.

Id.

120. See, e.g., Report of the Secretary-General, supra note 2, at Part III.E. (highlighting the argument of the International Association of Audio-visual Writers that copyright law as reflected in TRIPS has become unmoored from the justificatory principle of authors' rights, as protected in Continental law:

Copyright is not concerned with the protection of authors, but with the protection of works. . . [C] ] namely the creation itself, considerably reinforces the rights of producers as opposed to authors, and confers the same prerogatives on the producer that an author has with regard to users.

Id. at Part III.F (suggesting that the International Federation of Musicians' appeal for respect of the distinction between authors' rights and producers' rights, and expressing concern that copyright is being used by producers in ways that limit the creative freedom of musicians in particular).

121. General Comment No. 17, supra note 21. 
This historically informed interpretation dramatically reduces the tension that might otherwise be found between the two elements of the right to science and culture. When the right to protection is understood in this way, the two elements of the right to science and culture emerge as aligned. Protection of authors' interests in paternity and integrity also protects the public by ensuring access to cultural and scientific works in forms that preserve their original form and correct attribution. Indeed, a form of this argument was put forward at the Third Committee debates. ${ }^{122}$

\section{From 1948 to the Current Crossroads}

Legal and policy efforts to ensure widespread access to technology and culture have been rarely discussed as a human rights issue in recent decades. ${ }^{123}$ Yet this emerges from the historical view as a central commitment of the framers of the Universal Declaration of Human Rights. In the 1940s the international community not only insisted upon recognition of access to science and culture as a universal human right, they also established an international organization dedicated to realizing this vision. Protection of creators' interests was added to this broader vision of universal access.

Unfortunately, developments of the past sixty years have done more to obscure than to elucidate the purpose of Article 27. The original intention for the international bill of rights was to produce the Universal Declaration as a statement of principles in time for the UN General Assembly's first meeting in December 1948, then to complete the work of translating these principles into a binding treaty within the next few years. It was not to be. Cold War politics made it difficult to

122. Morsink reports the argument as follows:

Approaching the same moral right from a more populist perspective, Chang, the Chinese representative, argued that "the purpose of the joint amendment was not merely to protect creative artists but to safeguard the interests of everyone." For that reason, "literary, artistic and scientific works should be made accessible to the people directly in their original form. This could only be done if the moral rights of the creative artist were protected."

MORSINK, supra note 39, at 221-22.

123. See Chapman, Towards an Understanding, supra note 2, at 2 ("When science has been explicitly linked with human rights within the United Nations system it is usually within the framework of the relationship of science and technology to the realization of other human rights or, alternatively, the dangers that scientific developments and technologies can or do pose to the protection of human rights. But science is rarely, if ever, dealt with as a substantive human right."). Turning from the scientific to the cultural side of the equation, it is fair to say that while the freedom to enjoy one's culture without discrimination is well recognized as an issue of human rights, the socioeconomic dimension of access to opportunities to enjoy and participate in cultural life remains neglected. 
make international progress on human rights between 1948 and the fall of the Soviet Union. The vision for a unified human rights treaty was abandoned in favor of separate instruments for civil and political rights versus socioeconomic rights; the latter never won full support from the U.S. and dozens of other countries. Even these separate instruments would take until the mid-1960s to concretize and another decade yet to garner enough ratifications to come into force.

Even as serious attention has finally turned to socioeconomic rights over the past two decades, the right to science and culture has been all but overlooked. For many other provisions of international human rights law, the challenge of interpretation consists in pulling together and reconciling many different existing efforts. This existing material comes in the form of national constitutional court decisions, scholarly work, guiding documents of the United Nations bodies, and advice from human rights organizations and experts. Similar to a Restatement of Law, UN treaty committees draw on these resources to issue guidelines for interpretation and application of the right under study, called a General Comment.

For the right to science and culture, however, the challenge is rather different, and therefore much more complex. The passage of six decades has produced very little in the way of scholarly interpretation and even less in terms of national jurisprudence. For political reasons, UNESCO-which would have been the natural institutional home-has been discouraged from exercising leadership on this front. Although dozens of international civil society organizations exist to promote freedom of expression, the right to health, women's rights, or labor rights, there is presently no organization dedicated to promoting the right to science and culture. ${ }^{124}$ The challenge of interpretation for this right, then, is to make up for nearly six decades of missing work. This

124. Perhaps the closest candidate for this title is the American Association for the Advancement of Science's Program in Science and Human Rights program, which has as part of its mission "promoting the human right to enjoy the benefits of scientific progress." AAAS, AAAS Science and Human Rights Program, http://shr.aaas.org/ (last visited May 26, 2010). A number of organizations advocate policies internationally that would be highly in line with the right to science and culture, notably: 3D -> Trade, Human Rights, Equitable Economy, http://www.3dthree.org/ (last visited May 26, 2010); Creative Commons, http://creativecommons.org/ (last visited May 26, 2010); Electronic Frontier Foundation, http://www.eff.org/ (last visited May 26, 2010); and Knowledge Ecology International, http://keionline.org/ (last visited May 26, 2010). To the extent these organizations adopt a human rights framework for their advocacy, however, it is in terms of other human rights provisions, such as freedom of expression and the right to health. For further discussion of the relationship of rightsbased advocacy by these and similar organizations, visit Information Society Project at Yale Law School, http://yaleisp.org/2010/02/a2k4main/ (last visited May 26, 2010), to access summaries, videos, and other resources related to the conference, "A2K4: Access to Knowledge and Human Rights,” New Haven, CT, Feb. 11-13, 2010. 
consists, first, in articulating a persuasive proposal of how to translate and apply this norm, to which this Article is a first step. Reflecting the less well-developed scholarship and discourse on Article 27, there is not even a conventional short name for referring to this right as, for example, "the right to education" is widely used to refer to Article $26{ }^{125}$ The Universal Declaration did not provide headings for each of its Articles. The American Declaration did, however, include the right "to participate in the benefits that result from intellectual progress, especially scientific discoveries" alongside participation in cultural life beneath the heading "Right to the benefits of culture." 26

This term was apparently of unproblematic use in 1970, when Boutros Boutros-Ghali spoke of "the right to culture" as "the right of access to knowledge," including both taking part in cultural life and benefiting from scientific advancement. ${ }^{127}$ Today, however, discourse and scholarship on "cultural rights" refers primarily to Article 27 of a different instrument, which protects the distinctly narrower right of minority groups to preserve and enjoy their cultural traditions. ${ }^{128}$

125. This example makes clear that the lack of a short name cannot be blamed on the length or complexity of Article 27's text. The full text of Article 26 of the Universal Declaration contains three paragraphs, reading:

(1) Everyone has the right to education. Education shall be free, at least in the elementary and fundamental stages. Elementary education shall be compulsory. Technical and professional education shall be made generally available and higher education shall be equally accessible to all on the basis of merit.

(2) Education shall be directed to the full development of the human personality and to the strengthening of respect for human rights and fundamental freedoms. It shall promote understanding, tolerance and friendship among all nations, racial or religious groups, and shall further the activities of the United Nations for the maintenance of peace.

(3) Parents have a prior right to choose the kind of education that shall be given to their children.

Universal Declaration, supra note 1, at art. 26.

126. American Declaration, supra note 5, at art. XIII.

127. B. Boutros-Ghali, The Right to Culture and the Universal Declaration of Human Rights, in Cultural Rights AS Human Rights (1970), available at http://unescdoc.unesco.org/images/0000/000011/001194eo.pdf ("By the right of an individual to culture, it is to be understood that every man has the right of access to knowledge, to the arts and literature of all peoples, to take part in scientific advancement and to enjoy its benefits, to make his contribution towards the enrichment of cultural life.").

128. Article 27 of the International Covenant on Civil and Political Rights reads in full:

In those States in which ethnic, religious or linguistic minorities exist, persons belonging to such minorities shall not be denied the right, in community with the other members of their group, to enjoy their own 
Although the two Articles are clearly related, it is important not to conflate them. To avoid such confusion, I advocate the term "the right to science and culture" as preferable. This term is also useful, I suggest, in that it emphasizes the unity of science and culture, as well as the interrelatedness of the access and protection elements.

\section{A THEORY OF THE RIGHT TO SCIENCE AND CULTURE}

The first Part of this Article set the stage for an improved understanding of the right to science and culture by examining the historical context in which Article 27 was adopted. This historical view indicates that the framers sought to ensure that enjoyment of cultural life and new technologies would not remain an elite domain, but be made accessible and affordable to the common man. This commitment motivated not only the recognition of access to science and culture as a universal human right, but also the creation of an international organization dedicated to realizing this vision, UNESCO. Protection of creators' interests was added-as a controversial afterthought, the drafting history indicates-to this broader vision.

In this second Part of the Article, I build upon that original vision to flesh out a fuller framework for conceptualizing the specific legal obligations implicated by this understanding of the right to science and culture. Before proceeding into this more detailed analysis of how to understand the right to science and culture, however, it is important to visit three brief cautions on how not to understand it.

First, and most importantly, the right to science and culture must not be misunderstood as the recognition of a human right to IP protections along the lines of modern patent and copyright law. The conception of IP as a natural right to be protected against public demands for access emerged only very recently, and sits quite uneasily with foundational concepts of human rights. It would be a grave mistake to project concepts that developed in modern trade law-and which remain highly contested by contemporary legal scholars-onto the right to science and culture, which has quite a different historical origin and normative foundation.

The human rights approach to science and culture is quite different from the property approach and, as will be seen, the two frameworks are frequently in direct conflict. Rather than supporting the propertization of knowledge, the right to science and culture should be

culture, to profess and practice their own religion, or to use their own language.

International Covenant on Civil and Political Rights, G.A. Res. 2200A (XXI), art. 27, U.N. GAOR, 21st Sess., Supp. No. 16, U.N. Doc. A/6316 (Dec. 16, 1966). 
understood as a call for knowledge to be treated as a shared public resource, with international collaboration and universal access as touchstone commitments. Accordingly, the first Section of this Part connects the human rights framework's commitment to a participatory and inclusive vision of science and culture to the modern legal and economic literature on knowledge as a public good.

Second, the right to science and culture must also not be misunderstood as an empty bit of rhetoric that should not, or perhaps cannot, be given legal effect. The framers did not make a mistake when they included Article 27 in a list of universal human rights. The right to science and culture is not reducible to a mere development aspiration or common dream, subject to the ability of a particular society or individual to afford its realization.

Rather, Article 27 must be understood as the recognition of a universal right to science and culture, a commitment that the frontiers of human knowledge should not be treated as the domain of the privileged few but as the birthright of all. This is consistent with the cooperative and collaborative vision of equitable development and democratic society that defines the international human rights framework. The second Section of this Part examines how human rights law has developed to treat demands for access to other public goods, particularly health care and education. Drawing on this work, I suggest that it is both possible and desirable to give legal meaning to this right, to define specific state obligations in respect of it, to determine when the right has been violated and to legally vindicate it.

Third, the right to science and culture is not only, nor even primarily, about intellectual property. The right to science and culture has implications for public policy ranging from public funding for science and culture to Internet governance and telecommunications regulation, from education to health care, and from academic freedom to freedom of expression more generally.

Nevertheless, the topic of intellectual property poses special problems for the right to science and culture, because of its nature as an instance of legal limitations imposed on present-day access, in the name of longer-term improvements in innovation. The third and final Section of this Part takes up this tension between access and protection. Note that the concept of protection has an important dual meaning. On the one hand, it refers to the protection of intellectual property as required by international trade rules. On the other, it implies the protection of individual authors and inventors as required by the human rights treaties. Both aspects of protection are taken up in this exploration of how to reconcile multiple demands on the law as a tool of economic efficiency and social justice. 
Finally, although "science" and "culture" are invoked separately in both UNESCO's title and the Article 27 text, there is no clear dividing line between these two fields. ${ }^{129}$ In this context, "cultural life" does not refer to the narrow anthropological sense of traditional customs, but more broadly to areas of intellectual discovery and creativity in both the arts and sciences. It would thus be incorrect to suppose that the right to science impacts only patent law, and the right to culture impacts only copyright. The issues are inextricably related. Scientific exploration relies on the free exchange of information such as journal articles and databases, which may be limited by copyright. Cultural participation relies on access to information and communications technologies, which may be limited by patents. The same principles apply to interpreting and applying the right to take part in cultural life as well as the right to share in scientific and technological progress. This integrated approach is captured by my emphasis on the unifying concept of the "right to science and culture." It may also captured by the phrase "access to knowledge," which has been used with reference to the Article 27 right since at least $1966 .{ }^{130}$

\section{A. Knowledge as a Global Public Good}

Article 27 conceives of science, culture, and the arts -in short, the myriad expressions of human knowledge-as global public goods. In this way, it anticipates more recent scholarship in economics and law that identifies knowledge as a global public good and calls for reforms in intellectual property law to expand access.

The articulation of access to science and culture as the birthright of every human being was and remains a radical vision. It is not, however, a naîve one. Knowledge is a unique resource in that it actually increases, rather than being diminished, as it is shared.

129. See discussion supra notes 76-79 and accompanying text.

130. Articles 3-4 of the Declaration of Principles of International Cultural Cooperation state:

International cultural co-operation shall cover all aspects of intellectual and creative activities relating to education, science and culture. The aims of international cultural co-operation . . . shall be . . To enable everyone to have access to knowledge, to enjoy the arts and literature of all peoples, to share in advances made in science in all parts of the world and in the resulting benefits, and to contribute to the enrichment of cultural life.

Declaration of the Principles of International Cultural Co-operation, supra note 80 (emphasis added). See also Boutros-Ghali, supra note 127, at 73 ("By the right of an individual to culture, it is to be understood that every man has the right of access to knowledge, to the arts and literature of all peoples, to take part in scientific advancement and to enjoy its benefits, to make his contribution towards the enrichment of cultural life.") (emphasis added). 
Because of this nature, collaborative creativity and knowledge sharing are not only the most equitable approaches but also the most efficient.

The recognition of knowledge as a particularly valuable resource emerged only in the last half-century. Previously, economists had assumed that all economic growth was produced through the increasing application of labor and capital. In the postwar period, however, American economists such as Robert Solow, Moses Abramowitz, and Kenneth Arrow questioned this assumption. ${ }^{131}$ Technological change, learning, and innovation, they suggested, had to be considered as an additional driving factor. More recently, economic historian Joel Mokyr has persuasively argued that improvement in the production and diffusion of human knowledge is the most fundamental factor driving economic growth generally and key advances in social welfare particularly. ${ }^{132}$ To offer one dramatic example, the UN Development Programme estimated that the lives of approximately 3 million children were saved between 1980 and 1990 as a result of the adoption of just two new scientific breakthroughs: oral rehydration therapy and nextgeneration vaccines. ${ }^{133}$

The economic theory of public goods also has its origins in the 1950s. Building on the earlier work of economists-such as Emil Sax, Knut Wicksell, Erik Lindahl, Richard Musgrave, and Howard BowenPaul Samuelson famously articulated his theory of "collective consumption goods." 134 The economic term "nonrivalrous consumption" eventually emerged to describe these goods. Rival goods, such as housing or food, can be enjoyed only by a limited number of persons without being used up. In contrast, the availability of nonrival

131. Moses Abramovitz, Resource and Output Trends in the United States Since 1870, 46 AM. ECON. REv. 5 (1956); Kenneth J. Arrow, The Economic Implications of Learning by Doing, 29 REV. ECON. STUD. 155 (1962); Robert M. Solow, Technical Change and the Aggregate Production Function, 39 REv. ECON. \& STAT. 312 (1957).

132. Joel MOKYR, GifTS OF Athena: Historical ORigins OF THE KNOWLEDGE ECONOMY (2002). An excerpt from the introduction captures Mokyr's central argument in brief:

[L]iving standards are higher today than in the eleventh century primarily because we know more than medieval peasants. We do not say that we are smarter (there is little evidence that we are), and we cannot even be sure that we are richer that we used to be because we are better educated (although of course we are). The central phenomenon of the modern age is that as an aggregate, we know more.

Id. at 2.

133. United Nations Development Programme, human Development RePORT 2001: MAKING NeW TeChNOLOGIES WORK FOR Human DEVElopment 29 (2001).

134. Paul A. Samuelson, The Pure Theory of Public Expenditure, 36 REV. ECON. \& STAT. 387, 387 (1954). 
goods is not diminished as greater numbers of people enjoy access to them. ${ }^{135}$ Scientific knowledge and cultural works form a classic example of nonrivalry. ${ }^{136}$ Sharing a poem or teaching a concept to another person does not deprive the original possessor of its value. Samuelson's insight was that for this type of good, normal market mechanisms of price signaling would be inadequate to stimulate optimal provision; rather, organized public spending promised the most efficient outcomes. ${ }^{137}$

James Boyle has long argued that understanding the public good qualities of information is essential to the optimal design of intellectual property law. ${ }^{138}$ The strict definition of a public good, however, also incorporates a second criterion: that the good in question be not only non-rival, but also non-excludable. ${ }^{139}$ The first condition denotes that no one should, speaking strictly in terms of static economic efficiency, be excluded from sharing in a public resource. The second condition denotes that such exclusion is also impossible (or at least impracticable) as a matter of fact. ${ }^{140}$

This second criterion has particularly important implications for knowledge because IP protection makes this exclusion possible. Put another way, the function of intellectual property is to transform a global public good into a private one. This shift allows (in theory) for a more efficient market-based supply of knowledge goods. This privatization, however, comes at a cost. At least three new inefficiencies are introduced. First, some individuals who could have benefited from the resource will be priced out of access, reducing overall social welfare. Second, limited diffusion of new technologies may reduce macroeconomic efficiency in ways that reduce benefits to

135. Joseph E. Stiglitz, Knowledge as a Global Public Good, in GloBal PUBLIC GOODS: INTERNATIONAL COOPERATION IN THE 21ST CENTURY 308, 308-09 (Inge Kaul et al. eds., 1999). See also Yochai Benkler, The Wealth of Networks: How Social Production Transforms Markets and Freedom 36 (2006).

136. Thomas Jefferson is said to have described this characteristic of knowledge thus: " $[\mathrm{H}] \mathrm{e}$ who receives an idea from me, receives instruction himself without lessening mine; as he who lights his taper at mine, receives light without darkening me." Stiglitz, supra note 135, at 308. For a fuller picture of Jefferson's thoughts on knowledge as property, see Adam Mossoff, Who Cares What Thomas Jefferson Thought About Patents? Reevaluating the Patent "Privilege" in Historical Context, 92 CORNELL L. REV. 953 (2007).

137. Samuelson, supra note 134. Of course, practice was already ahead of theory, as governments had long invested in collective consumption goods such as national defense, law enforcement, public parks, and agricultural research.

138. James Boyle, Shamans, Software, and SpleEns: Law and the CONSTRUCTION OF THE INFORMATION SOCIETY (1996).

139. Stiglitz, supra note 135 , at 308-10.

140. Id. at 309. 
society as a whole. Third, because existing knowledge is also an input into the production of new knowledge, impeding the diffusion of knowledge resources will also tend to diminish innovation over the long term.

The argument in favor of intellectual property holds that these costs are outweighed by the benefits. Without IP protection, it has frequently been claimed, no incentives to create and invent would exist; knowledge would not advance and society as a whole would suffer greatly. ${ }^{141}$ This argument, however, lacks empirical support. The foundational law-and-economics treatise on intellectual property by Landes and Posner rejects the proposition as too speculative. ${ }^{142} \mathrm{~A}$ literature review by economist Adam Jaffe similarly concludes that a great quantity of empirical economics research has failed to prove the theoretical relationship between greater IP protection and greater innovation. ${ }^{143}$

In light of this uncertainty, legal scholars have increasingly questioned the extent to which IP is an economically efficient approach to promoting scientific and cultural innovation. As Yochai Benkler demonstrates, the theoretical assumption that only legal protection can provide incentives to create simply does not hold true in practice. ${ }^{144}$ Nor is it clear that the short-term cost of limiting diffusion is smaller than the long-term gain of additional incentives. ${ }^{145}$ Economic science remains fundamentally uncertain whether the current system of IP

141. See, e.g., Jeremy Bentham, The Rationale of Reward 318 (1830), http://books.google.com/books?id=6igN9srLgg8C ("In new inventions, protection against imitators is not less necessary than in established manufactures protection against thieves. He who has no hope that he shall reap will not take the trouble to sow."); John Bates Clark, Essentials of Economic Theory: As APPlied to MODERn PROBLEMS OF INDUSTRY AND PUBlic POLICY 360 (1918), http://books.google .com/books?id=ZmJMAAAAIAAJ ("If an invention became public property the moment that it was made, there would be small profit accruing to anyone from the use of it and smaller ones from making it.").

142. Landes and Posner state:

Given the emphases of the existing scholarly and popular literature concerned with intellectual property, it may come as a surprise to many readers that the economic arguments that we make for intellectual property protection are not based primarily on a belief that without legal protection the incentives to create such property would be inadequate. That belief cannot be defended confidently on the basis of current knowledge.

LANDES \& POSNER, supra note 30, at 9-10.

143. Jaffe, supra note 30.

144. BENKLER, supra note 135 , at $37-41$.

145. Id. at 37-39. See also James Boyle, The Public Domain: Enclosing THE COMMONS OF THE MIND 1-16 (2008). 
protection-or any other-in fact works more good than harm. ${ }^{146}$ Yet policy makers continue to expand IP protections ever upward, operating in what James Boyle refers to as "an evidence-free zone." 147

As illuminating as the economic perspective on intellectual property may be, economic analysis alone cannot tell the whole story. As Madhavi Sunder argues, the dominant economically oriented analysis of IP policy fails both "descriptively [and] prescriptively." 148 Cultural and scientific innovation is shaped by important non-economic incentives and motivations. The costs and benefits of IP protections, too, have implications far beyond economic efficiency. Intellectual property policy is cultural policy, writes Sunder. ${ }^{149}$ Intellectual property policy is scientific policy, notes Chapman. ${ }^{150}$ In either field, the choices made have dramatic implications for cultural and political freedom and for distributive justice and human dignity. ${ }^{151}$

Even economists have highlighted these broader aspects. As Joseph Stiglitz cautions, the optimal design of patent protection is not a purely technical problem, but a values-based judgment that creates winners and losers in the context of an unequal world. ${ }^{152}$ The construction of IP policy as a technical or economic issue outside the competency of human rights critique simply cannot be justified. Indeed, a rights-based approach might ultimately offer a better basis for rational

146. See, e.g., Richard A. Posner, Intellectual Property: The Law and Economics Approach, 19 J. EcoN. PersP. 57, 59 (2005) ("Unfortunately, economists do not know whether the existing system of intellectual property rights is, or for that matter whether any other system of intellectual property rights would be, a source of net social utility, given the costs of the system and the existence of alternatives sources of incentives to create such property.").

147. BOYLE, supra note 145, at 205-29.

148. Madhavi Sunder, IP 3 , 59 STAN. L. Rev. 257 (2006).

149. Id.

150. See Chapman, Development of Indicators, supra note 10, at 19-20, 2829.

151. See, e.g., Lawrence Lessig, Free Culture: How Big Media Uses Technology and the Law to Lock Down Culture and Control Creativity (2004); Jack M. Balkin, Digital Speech and Democratic Culture: $A$ Theory of Freedom of Expression for the Information Society, 79 N.Y.U. L. REV. 1 (2004).

152. Stiglitz states:

This discussion should have made clear one central point: the concept of intellectual property-the breadth, scope and applicability of patent protection-is not just a technical matter. There are judgment calls and trade-offs, with different people and different countries all affected differently by alternative decisions. There are conflicts of interests between developed countries and less developed countries. But unfortunately, many of the key issues cannot even be summarized by a set of simply stated principles. In practice, decisions are made on a case-by-case approach.

Stiglitz, supra note 135 , at 314. 
IP design than the economic approach. The implications of IP protection for human rights, at least, are susceptible to more certain evaluation than its implications for economic growth. Put another way: where is the logic in ignoring very real human freedoms and social benefits in favor of an exclusive focus on merely hypothetical economic gains?

The dominant, IP-maximalist approach treats the nature of knowledge as a public goods problem, to be solved by IP protection. Alternatively, however, we might conceive of science and culture as a public goods opportunity. As James Love of the advocacy group Knowledge Ecology International has noted, "[k]nowledge goods are also fundamentally different from physical goods and services. They can be copied. They can be shared. They do not have to be scarce. The rich and the poor can be more equal in knowledge goods than in many other areas." 153

Arguably, pursuing the public goods opportunity presented by science and culture is at the heart of the internationalist mission embraced by the Universal Declaration. Joseph Stiglitz has identified knowledge as one of five global public goods-the others being international economic stability, security and political stability, the international environment, and international humanitarian assistance. ${ }^{154}$ The provision of these global public goods was the very purpose for creating the United Nations and the international human rights framework. The belief was that we could not only directly enhance human welfare by collaborating to provide these goods, but that the process of collaboration itself would also pay dividends. Based upon this understanding, UNESCO has for decades sought to encourage collaborative approaches to generating and preserving knowledge as the common heritage of mankind. ${ }^{155}$

Moreover, the public goods opportunity presented by science and culture is a particularly promising one. Political scientist Scott Barrett has offered a useful framework for thinking about the collective action problems of realizing global public goods. ${ }^{156}$ According to Barrett's typology, some types of public goods are particularly difficult to achieve because their realization depends crucially on the efforts of those states that contribute least. An example of such a "weakest link"

153. James Love, KEI Remarks on Accepting the MacArthur Award for Creative and Effective Institutions, KEIONLINE.ORG, Oct. 5, 2006, http://www.keionline.org/node/432.

154. Stiglitz, supra note 135 , at 310.

155. Reichman et al., supra note 81.

156. See generally Scott Barrett, Why CoOperate? The Incentive to SUPPLY GLOBAL PUBLIC GOODS (2007). 
global public good is the eradication of a communicable disease such as smallpox. If even one country fails to make an adequate effort, the entire endeavor can fail. ${ }^{157}$ At the other end of the spectrum lie the "single best effort" global public goods, which are the easiest to produce. Here, the good can successfully be supplied to all, if even a single actor puts forward a sufficient effort, although the likelihood of success typically increases with collaboration. As an example of this type of global public good, Barrett offers the hypothetical instance of the need to divert an asteroid from hitting the earth. ${ }^{158}$

Unlike the other four global public goods identified by Stiglitz, knowledge uniquely falls in Barrett's "single best effort" category. Indeed, Barrett also offers the example of the polio vaccine as a secondary illustration of a "single best effort" global public good. ${ }^{159}$ Actors in the U.S. did not realize, at the time they pursued the development of the vaccine, that it would eventually benefit millions of people worldwide. Acting only in national self-interest, they mobilized sufficient resources to solve the scientific challenge. ${ }^{160} \mathrm{~A}$ later international campaign to immunize children worldwide represented an effort to take advantage of the global public good opportunity provided by the vaccine's availability. As Yochai Benkler elaborates, goods that are inexpensively reproduced-such as cultural works, information, and know-how-are the easiest to supply through social production models, rather than market-based models. ${ }^{161}$

Much has been made of the moral hazard of "free riding" in the provision of public goods. This represents the possibility that many actors will choose not to invest resources in worthy causes, knowing they can wait until others do the work, then share in the benefits. The risks of free riding, however, should be understood to vary with different types of public goods. In Barrett's "weakest link" model, any instance of free riding will prevent the success of a common project. In the "single best effort" category, however, free riding need not be understood as a harm. If sufficient incentives and opportunities exist for someone to initially come up with an innovation-public mindedness, government procurement, business advantage through innovation lead time, or simple human curiosity - the possibility for others to ride on these coattails represents a gain for all, but particularly for the less well-off.

157. Id. at $47-48$.

158. Id. at 22-24.

159. Id. at 22 .

160. Id.

161. BENKLER, supra note 135 , at 91-132. 
The choice of which approach to take to the production of science and culture-sharing or propertization-is a consequential one. And a choice between these two models is required. The very measures taken to promote the production of knowledge under the propertization model stifle its production under the sharing model. By overwhelmingly promoting the privatization of knowledge, we rob individuals of opportunities to take part in cultural life and enjoy the fruits of scientific progress. We also impoverish society as whole, by turning a unique opportunity for shared international endeavor in the service of mankind into just another commodity.

\section{B. Socioeconomic Rights and Universal Access}

The previous Section proposed that interpreters of the right to science and culture should begin with an understanding of knowledge as a global public good. How does this vision, however, translate into concrete and specific human rights responsibilities capable of being enforced by courts and other institutional agents of human rights accountability? To answer this question, it is necessary to look at the right to science and culture within the broader context of socioeconomic rights as protected by the International Covenant on Economic, Social and Cultural Rights (ICESCR).

Whereas the rights protected by the International Covenant on Civil and Political Rights (i.e., freedom of expression, the right to vote, due process, and freedom from discrimination) are very familiar to U.S. legal scholars, those contained in the ICESCR rights may seem more foreign. ${ }^{162}$ The socioeconomic rights embodied in this treaty are often referred to as the "second generation" rights because they have a shorter international history of constitutional recognition and judicial protection. ${ }^{163}$ Although never incorporated into U.S. jurisprudence, they are widely accepted internationally, and most national constitutions written post-World War II recognize them in detail. Despite formal recognition as co-equal with the "first generation" civil and political rights, however, socioeconomic rights are less frequently litigated, and remain more controversial even among human rights scholars. ${ }^{164}$

162. But see SUNSTEIN, supra note 41 (highlighting the American roots of the push to recognize second-generation rights in international law and explaining why the doctrine failed to take hold domestically, despite succeeding internationally).

163. See generally Henry J. STEINER \& PhILIP ALston, InTERnational Human Rights in CONTEXT: LaW Politics, Morals 237-320 (2d ed. 2000) (offering historical, conceptual, and political background on the second generation socioeconomic rights, compared to the first generation civil and political rights).

164. The state of the debate is well summarized by Steiner and Alston: 
One reason for this differing treatment has been political: U.S. hostility for recognition of socioeconomic claims as human rights since the end of the New Deal era. This hostility is partly rooted in the context of domestic regional politics and the Jim Crow era, but also the Cold War and fear of Communism. In the 1950s, the original unified vision of the Universal Declaration of Human Rights was translated into two separate Covenants, only one of which the U.S. Senate ultimately ratified. $^{165}$

The second-class nature of the second generation rights also reflects a catch-22 dilemma. Without a long tradition of jurisprudence to define the precise contours of these rights, the rights may seem too

The "official" position, dating back to the Universal Declaration and reaffirmed in innumerable resolutions since that time, is that the two covenants and sets of rights are, in the words adopted by the second World Conference on Human Rights in Vienna, "universal, indivisible and interdependent and interrelated. The international community must treat human rights globally in a fair and equal manner, on the same footing, and with the same emphasis." (Vienna Declaration, para. 5) But this formal consensus masks a deep and enduring disagreement over the proper status of economic, social and cultural rights. At one extreme lies the view that these rights are superior to civil and political rights in terms of an appropriate value hierarchy and in chronological terms. Of what use is the right to free speech to those who are starving and illiterate? At the other extreme we find the view that economic and social rights do not constitute rights (as properly understood) at all. Treating them as rights undermines the enjoyment of individual freedom, distorts the functioning of free markets by justifying large-scale state intervention in the economy, and provides an excuse to downgrade the importance of civil and political rights.

Although variations on these extremes have dominated both diplomatic and academic discourse, the great majority of governments have taken some sort of intermediate position. For the most part that position has involved (a) support for the equal status of economic and social rights (as of March 2000, 142 states were parties to the ICESCR, compared with 144 parties to the ICCPR), together with (b) failure to take steps to entrench those rights constitutionally, to adopt legislative or administrative provisions based explicitly on the recognition of specific economic and social rights as international human rights, or to provide effective means of redress to individuals or groups alleging violations of those rights. Indeed, one of the puzzles in the field lies in the rare invocation of the ICESCR in the play of internal politics or in the judiciaries in most states, compared with the frequent invocation of civil and political rights provisions of the UDHR, the ICCPR, and regional instruments such as the European Convention on Human Rights.

Id. at 237-38.

165. SUNSTEIN, supra note 41, at 101-08; International Covenant on Civil and Political Rights, supra note 128 (ratified June 8, 1992, entered into force Mar. 23, 1976); ICESCR, supra note 5 (entered into force Jan. 3, 1976; signed by President Carter but never ratified by the Senate). 
diffuse or unclear to adjudicate. As jurists and litigants avoid asserting or relying on the less well-defined rights, they perpetuate the marginalization.

For a time, the dearth of judicial treatment led many human rights scholars and advocates to conclude that socioeconomic rights were incapable of adjudication. Contrary to civil and political rights, this perspective held, socioeconomic rights claims were so inherently vague and uniquely dependent upon economic resources that it would be impossible to define any point at which the right could be said to be violated. ${ }^{166}$ According to this view the "rights" to health and education, for instance, must be understood solely as aspirational goals to be pursued over decades as economic growth permitted. ${ }^{167}$ Apart from the bedrock norm of nondiscrimination, these rights were wholly subject to the logic of "progressive realization." 168

Responding to the challenge, an international group of scholars worked to build the conceptual foundations of a "violations" approach to socioeconomic rights. ${ }^{169}$ This work resulted in a number of new conceptual and interpretative tools that now enjoy widespread acceptance and formal legal recognition. ${ }^{170}$ As a reflection of this shift, national courts have, over the past decade or so, increasingly vindicated socioeconomic rights claims. ${ }^{171}$

The most important recognition of the shifting tide on the justiciability of socioeconomic rights is the recent adoption of an

166. This view is captured in the 1986 expert consensus. ECOSOC, Comm'n on Human Rights, The Limburg Principles on the Implementation of the International Covenant on Economic, Social and Cultural Rights, ๆ1 11-58, 43d Sess., Annex, U.N. Doc. No. E/CN.4/1987/17 (Jan. 8, 1987) [hereinafter Limburg Principles] (prepared by the Kingdom of The Netherlands).

167. Id.

168. Id. The requirement of "progressive realization" may be analogized to Brown v. Board of Education's invocation of "with all deliberate speed." See 349 U.S. 294, 301 (1955).

169. See Audrey R. Chapman, $A$ "Violations Approach" for Monitoring the International Covenant on Economic, Social and Cultural Rights, 18 Hum. RTs. Q. 23 (1996).

170. ECOSOC, Comm. on Econ., Soc. \& Cultural Rights, The Maastricht Guidelines on Violations of Economic, Social and Cultural Rights, 24th Sess., U.N. Doc. E/C.12/2000/13 (Nov. 27, 2000) [hereinafter Maastricht Guidelines] (a statement of expert consensus reflecting shifts in the conceptualization of socioeconomic rights enforceability since 1986).

171. See, e.g., Eric C. Christiansen, Adjudicating Non-Justiciable Rights: Socio-Economic Rights and the South African Constitutional Court, 38 Colum. HuM. RTs. L. Rev. 321 (2007); John Cantius Mubangizi, The Constitutional Protection of Socio-Economic Rights in Selected African Countries: A Comparative Evaluation, 2 AFR. J. LEGAL STUD. 1 (2006). 
Optional Protocol to the ICESCR. ${ }^{172}$ With this act, the international community has voted to empower the Committee on Economic, Social and Cultural Rights to hear claims of socioeconomic rights violations. ${ }^{173}$ Only States parties to the ICESCR that choose to sign the optional protocol will be subject to the Committee's jurisdiction. ${ }^{174}$ Admission of complaints will be subject to normal principles of exhaustion of remedies, meaning that the CESCR will typically hear cases on appeal from national courts of final appeal. ${ }^{175}$

A similar Optional Protocol was established for civil and political rights in $1966 .{ }^{176}$ Adoption of the intended protocol for the ICESCR, however, was delayed for more than four decades. ${ }^{177}$ Only recently has the consensus emerged that socioeconomic rights enjoy sufficient normative clarity to make such an adjudicatory process appropriate. ${ }^{178}$

172. Optional Protocol to the International Covenant on Economic, Social \& Cultural Rights, G.A. Res. 63/117, 63d Sess., 66th plen. mtg., U.N. Doc. A/RES/63/117 (Dec. 10, 2008) (adopting the optional protocol to allow for individual complaints to the Committee on Economic, Social and Cultural Rights and annexing the full text of the optional protocol).

173. Id. at arts. $1-2,5-12$. The procedures outlined here are substantially similar to the practice of the Inter-American Human Rights System. See Lea Shaver, The Inter-American Human Rights System: An Effective Institution for Regional Rights Promotion?, WASH. U. Global. StUD. L. REv. (forthcoming), available at http://ssrn.com/abstract $=1437633$.

174. Optional Protocol to the International Covenant on Economic, Social \& Cultural Rights, supra note 172, at art. 1.

175. Id. at art. 3.

176. Optional Protocol to the International Covenant on Civil \& Political Rights, G.A. Res. 2200A (XXI), 21 U.N. GAOR, Supp. No. 16, at 59, U.N. Doc. A/6316 (1966) (entered into force Mar. 23, 1976).

177. The ICESCR was adopted on December 16, 1966. See sources cited supra note 5. The ICESCR's Optional Protocol was adopted forty-two years later, on December 10, 2008. See sources cited supra note 172.

178. See M. Magdalena Sepúlveda, The Nature of the Obligations UNDER THE INTERNATIONAL COVENANT ON ECONOMIC, SOCIAL AND CULTURAL RightS 427-33 (2003) (summarizing recent developments in conceptualizing the ICESCR). Writing in 2003, Sepulveda concluded:

During the early discussions regarding the adoption of an optional protocol, some commentators argued that it was premature to adopt such an instrument. It was considered essential to further develop the normative content of Covenant before proceeding to adopt an individual complaints procedure. The present study demonstrated that these arguments against the adoption of an optional protocol are no longer tenable. Such arguments are insensitive to the developments achieved in the clarification of the normative content of the Covenant during recent years. The current level of understanding of the normative content of the Covenant is such that it could be suitably reinforced through the adoption of a complaints procedure.

Id. at 429 . 
This normative clarity takes two forms: first, a set of interpretative concepts and principles applicable to socioeconomic rights generally; ${ }^{179}$ second, concrete guidelines on state obligations with regard to specific rights. ${ }^{180}$

Several key concepts present in this doctrinal corpus bear emphasis as essential to the interpretation of Article 27. These include: nondiscrimination, ${ }^{181}$ progressive realization, ${ }^{182}$ minimum core obligations, ${ }^{183}$ direct and horizontal application, ${ }^{184}$ and the duties to respect, protect, and fulfill. ${ }^{185}$ These concepts provide essential tools for interpreting the content and scope of state obligations in respect of specific socioeconomic rights, including the right to science and culture.

Agreement on these principles in the abstract does not mean that their application to any specific right will be simple or without controversy. Applying rights claims to real-world situations is always a challenging task that requires no small portion of skill and judgment

179. See, e.g., Maastricht Guidelines, supra note 170; ECOSOC, Comm. on Econ., Soc. \& Cultural Rights, General Comment No. 3: The Nature of States Parties' Obligations, 83, 86, 5th Sess., Supp. No. 3, Annex III, U.N. Doc. E/1991/23 (1990) [hereinafter General Comment No. 3]; ECOSOC, Comm. on Econ., Soc. \& Cultural Rights, Draft General Comment No. 9: The Domestic Application of the Covenant, 19th Sess., U.N. Doc. E/C.12/1998/24 (Dec. 3, 1998) [hereinafter General Comment No. 9]; ECOSOC, Comm. on Econ., Soc. \& Cultural Rights, General Comment No. 16: The Equal Right of Men and Women to the Enjoyment of All Economic, Social and Cultural Rights (art. 3 of the International Covenant on Economic, Social and Cultural Rights), 34th Sess., U.N. Doc. E/C.12/2005/3 (Aug. 11, 2005) [hereinafter General Comment No. 16]; ECOSOC, Comm. on Econ., Soc. \& Cultural Rights, General Comment No. 20: Non-Discrimination in Economic, Social and Cultural Rights (art. 2, para. 2, of the International Covenant on Economic, Social and Cultural Rights), 42d Sess., U.N. Doc. E/C.12/GC/20 (July 2, 2009) [hereinafter General Comment No. 20].

180. See, e.g., General Comment No. 17, supra note 21 (analyzing the obligations of states parties to the ICESCR with respect to the right to protection of the moral and material interests of authors).

181. See Limburg Principles, supra note 166, at 19 35-45; Maastricht Guidelines, supra note 170, at I1 11-12, 14(b); General Comment No. 3, supra note 179, at II 1, 3, 5; General Comment No. 9, supra note 179, at If 9, 15; General Comment No. 20, supra note 179.

182. See Limburg Principles, supra note 166, at If 21-24; Maastricht Guidelines, supra note 170, at \8; General Comment No. 3, supra note 179, at $\$ 1$.

183. See Maastricht Guidelines, supra note 170, at I 9; General Comment No. 3, supra note 179 , at 10.

184. Within modern human rights doctrine, it is equally a violation of the right for the state to actively restrict enjoyment of the right, as well as for the state to fail to prevent other private parties from restricting enjoyment of the right. See Maastricht Guidelines, supra note 170, at 9f 14-15 (especially 15(d)).

185. See id. at I 6; General Comment No. 17, supra note 21, at $\$ 28$. 
and that relies more frequently than not upon the application of inherently subjective value frameworks.

Nevertheless, these tools provide an essential starting point for doctrinal development. Audrey Chapman has recently offered the first analysis of how these concepts may be applied to elaborate the right to science and culture, with emphasis on the scientific aspect. ${ }^{186}$ Her list of specific state obligations that may be inferred from this right seems to me an excellent starting point. ${ }^{187}$ A colleague and I have recently made an effort at a similar endeavor, with emphasis on the cultural aspect of the right. ${ }^{188}$

Chapman's work notes concerns-particularly post-TRIPS-that intellectual property protections may be in conflict with human rights obligations. ${ }^{189}$ The recent Venice Statement of human rights experts also notes that "the right to enjoy the benefits of scientific progress and its applications may create tensions with the intellectual property regime." 190 Yet both Chapman's article and the Venice Statement stop short of offering specific advice on whether-and how-intellectual property should be reformed to respect the right to science and culture. ${ }^{191}$ In the following final Section of this Part, I approach this difficult question through the lens of reconciling the tension between the access and protection elements of the right.

186. Chapman, Towards an Understanding, supra note 2, at 18-25.

187. The specific obligations Chapman identifies are to refrain from interfering with the freedom of scientific research and communication, id. at 18; to protect people from applications of harmful technologies, id. at 21-22; to ensure informed consent and precautionary procedures in scientific research involving human subjects, id. at 21-22; to direct public investment into research of likely social benefit, particularly to poor and disadvantaged groups, id. at 25 ; and to develop a strong program of scientific education, id.

188. Shaver \& Sganga, supra note 76.

189. Chapman, supra note 2, at 19-20. See supra note 3 and accompanying text.

190. Venice Statement on the Right to Enjoy the Benefits of Scientific Progress and its Applications Venice \10, Statement of Expert Group convened by UNESCO in Venice, Italy, July 16-17, 2009, available at http://unesdoc.unesco.org/images/0018/ $001855 / 185558$ e.pdf [hereinafter Venice Statement].

191. The Venice Statement includes its caution about the tension with IP protection as one of five key conceptual challenges facing the right. Id. at 91 7-11. Later, the Statement lists specific obligations of states parties within the framework of "respect, protect, and fulfil," closely mirroring the work of Chapman. Id. at 99 14-16; Chapman, Towards an Understanding, supra note 2 , at 18 . None of the recommendations in this list, however, pertain to IP policy. It would seem that the group could not reach agreement on what, specifically, to say about states' obligations to address the tensions between IP protections and human rights. 


\section{Reconciling Access and Protection}

In elaborating this theory of the right to science and culture, I have placed particular emphasis on the concept of access. To be sure, "access" is not the whole of the right to science and culture. Apart from its emphasis on ensuring universal access, treaty language also points toward state duties to protect the interests of authors and creators, ${ }^{192}$ to respect scientific and cultural liberty, ${ }^{193}$ and to promote international collaboration. ${ }^{194}$ The touchstone concept of the right to science and culture, however, must be access. This concept is inherent in the earliest formulation of the right, which spoke simply of the right of all peoples to take part in cultural life, to enjoy the arts, and to share in the benefits of scientific progress. ${ }^{195}$ The addition of an element mandating protection of creators' and inventors' interests was justified in terms of its compatibility with and service to this original and primary element. ${ }^{196}$ The even later language making explicit the values of liberty and internationalism is likewise justified with reference to this initial aim. ${ }^{197}$

192. ICESCR, infra note 5, at art. 15(1)(c).

193. Id. at art. 15(3).

194. Id. at art. 15(4)

195. See discussion of Article 27 as it appeared in the first draft of the Universal Declaration of Human Rights in 1947, supra note 83 and accompanying text. This original "access" provision corresponds to Article 15(1)(a)-(b) of the ICESCR:

1. The States Parties to the present Covenant recognize the right of everyone:

(a) To take part in cultural life;

(b) To enjoy the benefits of scientific progress and its applications;

ICESCR, supra note 5, at art. 15(1)(a)-(b).

196. See discussion of arguments and justifications argued for the addition of a "protection" provision to Article 27 in the Universal Declaration of Human Rights as adopted in 1948, supra notes 120-122 and accompanying text. The added language corresponds to Article 15(1)(c) of the ICESCR, recognizing the right of everyone:

(c) To benefit from the protection of the moral and material interests resulting from any scientific, literary or artistic production of which he is the author.

ICESCR, supra note 5, at art. 15(1)(c).

197. I refer here to Article 15(2)-(4) of the ICESCR as adopted in 1966, which has no corollary in the Universal Declaration of Human Rights. The text reads:

2. The steps to be taken by the States Parties to the present Covenant to achieve the full realization of this right shall include those necessary for the conservation, the development and the diffusion of science and culture.

3. The States Parties to the present Covenant undertake to respect the freedom indispensable for scientific research and creative activity. 
Although universal access to science and culture was and remains the core value of the right, it has proved over time to be the most controversial and difficult element to elaborate. As international trade law has increasingly embraced the logic of knowledge privatization and protection, science and culture seem more and more like luxury goods. Within this market-focused logic, access is a simple function of willingness and ability to pay the prevailing rate. How could it be otherwise?

In developing the meaning of the obligation to ensure access with respect to science and culture, it is possible to draw on existing scholarship and jurisprudence developed in the context of other socioeconomic rights. The right to education, for instance, encompasses both liberty and access dimensions. ${ }^{198}$ The same is true for the right to health, ${ }^{199}$ the right to food, ${ }^{200}$ and the right to water. ${ }^{201}$ Socioeconomic rights, by definition, deal with basic needs essential to human survival and dignity to which all people may not have access in the absence of state assistance. Therefore, specifying the exact nature of the access that states are required to ensure has been a key topic for the conceptualization of these rights.

Access has been defined by international human rights law to have multiple dimensions. The requisite access is satisfied only when the

4. The States Parties to the present Covenant recognize the benefits to be derived from the encouragement and development of international contacts and co-operation in the scientific and cultural fields.

ICESCR, supra note 5, at art. 15(2)-(4).

198. ECOSOC, Comm. on Econ., Soc. \& Cultural Rights, General Comment No. 13: The Right to Education (article 13 of the Covenant), I 6-7, 28-30, 21st Sess., U.N. Doc. E/C.12/1999/10 (1999) [hereinafter General Comment No. 13].

Liberty aspects of the right to education include the liberty of parents to ensure their children's education reflects their own religious and moral convictions, the freedom to establish private educational institutions, and the freedom to attend or send one's child to one. Id. at 18 28-30.

Access aspects of the right require access to educational opportunities which are physically and economically accessible to all students without discrimination, acceptable in terms of both quality and cultural relevance, and adaptable to the needs to students in a diverse and changing society. Id. at II 6-7.

199. ECOSOC, Comm. on Econ., Soc. \& Cultural Rights, General Comment No. 14: The Tight to the Highest Attainable Standard of Health (article 12 of the International Covenant on Economic, Social and Cultural Rights), 22d Sess., U.N. Doc. E/C.12/2000/4 (2000) [hereinafter General Comment No. 14].

200. ECOSOC, Comm. on Econ., Soc. \& Cultural Rights, General Comment No. 12: Right to Adequate Food (art. 11), 20th Sess., U.N. Doc. E/C.12/1999/5 (May 12, 1999) [hereinafter General Comment No. 12].

201. ECOSOC, Comm. on Econ., Soc. \& Cultural Rights, General Comment No. 15: The Right to Water (arts. 11 and 12 of the Intemational Covenant on Economic, Social and Cultural Rights), 29th Sess., U.N. Doc. E/C.12/2002/11 (2002) [hereinafter General Comment No. 15]. 
good is physically accessible to all (geographic availability and accommodations of disability), affordable, of acceptable quality, culturally appropriate, and adaptable to the particular needs of the community and individual. ${ }^{202}$ These standard dimensions of access are also relevant for thinking about access to technological and cultural goods and experiences. The dimensions of access also require some adaptability from right to right. For instance, with respect to the right to food, the requisite access might be achieved by making it possible for families to grow their own crops and raise animals. ${ }^{203}$ In the context of education, an organized system of public provision, generally at no cost to the recipient, is required. ${ }^{204}$

In the context of the right to science and culture, "access" has multiple dimensions. It should be understood to include the ability to actively participate and share with others, not merely to play the passive role of consumer. As Caterina Sganga and I have written elsewhere, "[t]he right 'to take part in' culture consists in the ability to consume and to create, individually and with others. Culture exists to be shared and to inhabit a culture is to contribute to it." ${ }^{205}$ Participation, as well as consumption, is the essence of the right to science and culture. "Access" therefore should be understood in terms of access to scientific and cultural materials, tools, and information; access to opportunities to create as well as to consume; and to share in the senses of both taking and giving. Looking to the scientific aspect of the right, access must go beyond sharing in the diffuse benefits of scientific learning in its pure form. The treaty language specifies the right to enjoy the benefits "of scientific progress and its applications." ${ }^{206}$ Everyone is meant to enjoy access to and benefit from new technological discoveries.

This access may be promoted in many ways. During the New Deal, the United States adopted policy initiatives to expand access to electricity and support public cultural initiatives. ${ }^{207}$ More recently, South Korea has invested heavily in a national Internet infrastructure to lead the world in access to broadband connectivity. ${ }^{208}$ Almost every nation supports public universities, funds research in health and agriculture, and supports national artistic and cultural institutions and

202. See supra notes 198-201 and accompanying text.

203. General Comment No. 12, supra note 200, at 12.

204. General Comment No. 13, supra note 198, at 6(b).

205. Shaver \& Sganga, supra note 76, at 9.

206. ICESCR, supra note 5, at art. 15(1)(b).

207. See supra notes 52-58 and 68-75 and accompanying text.

208. Arnold Picot \& Christian Wernick, The Role of Government in Broadband Access, 31 TELECOMMS. PoL'y 660, 667 (2007). 
museums. The One Laptop Per Child initiative is an effort to provide free, Internet-capable computers to millions of children in the developing world. ${ }^{209}$ These initiatives all represent efforts to fulfill the right of access to science and culture by direct provision.

Many of these approaches will be cost-prohibitive, however, for developing countries. ${ }^{210}$ For these countries, as well as those with greater resources, I suggest that a focus on removing IP barriers to access may be a particularly cost-effective starting point.

Intellectual property protection, at least in its current implementation, represents the power to exclude others from using, sharing or adapting a work or idea. As such, it inevitably constitutes a barrier to access. A direct barrier is imposed to the follow-on creator or inventor who would seek to incorporate elements of the protected work into their own innovations. Indirect barriers are raised to society generally, which will not enjoy access to the follow-on creation that was so blocked. Economic barriers are raised to consumers, who must pay more to purchase access to a cultural work or technology because competition in its production is artificially limited. Moreover, this is not an inevitable or natural barrier, but one created and maintained by state action. Normally, expanding access to a socioeconomic rightsuch as education or health care-requires vast sums of money. Intellectual property represents a unique case where governments actually spend resources-on IP administration and enforcement-to artificially limit access to enjoyment of a human right.

The imposition of such barriers might be justified in human rights terms, however, if they are necessary to advance other rights. It may be asserted, for instance, that even if IP protection may be in conflict with the "access" elements of the right to science and culture, it is necessary to realize the "protection" element of the right. The strong form of this argument would suggest that the right of access to knowledge begins only where IP protection ends.

Yet the historical view suggests that the right to science and culture should in fact be interpreted in exactly the opposite manner. ${ }^{211}$ The right to science and culture's original emphasis was on the right of access, which was unanimously supported. ${ }^{212}$ In contrast, the "protection" element was added later, and sparked unusual controversy from delegates who believed it was inappropriate for inclusion in a

209. Kenneth Kraemer et al., One Laptop Per Child: Vision vs. Reality, 52 Comms. A.C.M. 66, 66 (2009), available at http://mags.acm.org/communications/ $200906 /$ folio $=66 \&$ CFID $=79755081 \&$ CFTOKEN $=52488147$.

210. Chapman, Towards an Understanding, supra note 2, at 31.

211. See supra Part I.

212. See supra notes $83-84$ and accompanying text. 
statement of human rights. ${ }^{213}$ This context suggests that it would be inappropriate to interpret the access element of the right as limited by protection element. Rather, the protection element should be given an interpretation that is compatible with the original and primary emphasis on access.

Such an interpretation is indeed possible. As noted in Part I of this Article, the drafting history strongly suggests that the "protection" element of the right should be understood in a way that does not require trade-offs with the "access" element. ${ }^{214}$ This is because the phrase "moral and material interests" of authors and creators ${ }^{215}$ was not intended as a euphemism for IP protection, but rather as a related doctrine compatible with a number of approaches to IP policy. ${ }^{216}$ These could, I suggest, include greatly reduced terms of protection, greatly expanded exceptions and limitations, or the choice of developing nations in particular to refuse IP protection on the grounds that its availability in larger markets creates sufficient economic opportunity. Alternatively, the moral and material interests of authors and inventors could also-arguably better-be protected through abandoning the exclusive property concept in favor of a liability approach of the sort described by Jerome Reichman. ${ }^{217}$ Again, this approach can be compatible with substantial limitations and exceptions to leave room for free uses for nonprofit purposes.

If substantial restrictions on the public's access to knowledge of the sort imposed by modern IP regimes are not required by the human rights framework, might they nevertheless be permitted? The standard justification for IP holds that although IP protections restrict competition and limit access in the present, such sacrifices are necessary to ensure the incentives for future innovation. ${ }^{218}$ As discussed above, this assertion rests upon little empirical support. ${ }^{219}$ Human rights

213. See supra Part I.B.

214. See supra notes 114-122 and accompanying text.

215. Universal Declaration, supra note 1, at art. 27(2).

216. See supra notes 116-121 and accompanying text.

217. See generally J.H. Reichman, Legal Hybrids Between the Patent and Copyright Paradigms, 94 Colum. L. REV. 2432 (1994); J.H. Reichman, Of Green Tulips and Legal Kudzu: Repackaging Rights in Subpatentable Innovation, 53 VAND. L. REV. 1743 (2000); Jerome H. Reichman \& Tracy Lewis, Using Liability Rules to Stimulate Local Innovation in Developing Countries: Application to Traditional Knowledge, in InTERnational Public Goods and Transfer of Technology Under a Globalized Intellectual Property Regime 337-38 (Keith E. Maskus \& Jerome H. Reichman eds., 2005).

218. The centrality to IP policy of this trade-off between static and dynamic efficiency is best explained by economist Keith Maskus. KEITH E. MASKUS, INTELlECTUAL PRoperty Rights IN THE Global ECONOMY 28-33 (2000).

219. See supra notes 141-147 and accompanying text. 
advocates should be aggressive in challenging it. Judges, ultimately, must decide if they will defer to the mere invocation of a plausible public interest or actively question the justifications given for limiting human rights, insisting on evidence-based policy making and narrow tailoring of restrictions on public access. I recommend the latter.

A second possible defense of IP-based exclusions in human rights terms would be that IP protection merely delays, rather than denies, the right of access. Patent terms, at least, run for only twenty years. ${ }^{220}$ Then, in theory, prices should come down to levels that the masses can afford. Yet in a very real sense, rights delayed are rights denied. Had access to oral rehydration therapy and second-generation vaccine technologies been delayed for twenty years, to invoke an earlier example, three million children would have died. ${ }^{221}$ Even for less lifeand-death technologies, a twenty-year delay works an immense limitation on enjoyment of the right. For cultural works, the situation is even worse; protection lasts longer than a human lifetime. ${ }^{222}$ How real is the concept of cultural participation if people cannot participate simultaneously?

\section{IMPLICATIONS FOR INTELLECTUAL PROPERTY LAW}

Part II of this Article outlined a theoretical foundation for the right to science and culture, drawing upon concepts from recent scholarship in the areas of IP and socioeconomic rights. This third and final Part examines the more problematic translation of this theory into practice. Does the right to science and culture translate into any positive legal obligations that may be enforced in courts? If so, what are these obligations? When, if ever, is it possible to say that the right to science and culture has been violated, and in such a case, what would be the appropriate remedy? What implications would a restored recognition and enforcement of the right to science and culture have for other areas of the law, particularly intellectual property? These questions are the subject of this Part.

The first Section examines the legal status of the right to science and culture as recognized, inter alia, at Article 27 of the Universal Declaration. Because the Universal Declaration is merely a resolution of the UN General Assembly rather than a treaty, it creates no binding obligations as a matter of international law. The right has, however,

220. A twenty-year term of patent protection is the current international standard in accordance with the floor set by TRIPS. TRIPS, supra note 34, at art. 33.

221. See United Nations Development Programme, supra note 133, at 29.

222. The current international standard for most copyrighted works is life of the author plus fifty years, a floor set by TRIPS. TRIPS, supra note 34, at art. 12. 
been translated into other binding treaties to which a majority of states are parties. The Section goes beyond the formalities of international law, however, to examine more subtle modes of normative influence from human rights law on other bodies of law, including international trade law.

The second and final Section examines head-on the conflict between the conception of the right to science and culture developed in this Article and international IP law as it stands today. Here I discuss how the introduction of human rights arguments can help to reform elements of the current international IP regime that are harmful not only to human rights but also to economic growth. I also suggest how human rights and access to knowledge advocates might most strategically pursue this potential.

\section{A. The Legal Status of the Right to Science and Culture}

Although the Universal Declaration is considered to be the foundational text of international human rights law, it does not itself create binding treaty obligations, being merely a resolution of the UN General Assembly. Similarly, the American Declaration, which recognizes the right to science and culture at its Article XIII, is a resolution of the Organization of American States and therefore does not create treaty obligations on any state. Several other United Nations declarations or resolutions also bear some relevance to the right to science and culture. ${ }^{223}$ Again, these are non-binding instruments.

As a matter of international law, the non-treaty documents described above create no binding legal obligations upon any State; they do, however, constitute an important part of the "soft law" body of international human rights norms. ${ }^{224}$ Many nations choose, as a matter of domestic law, to incorporate these documents into their constitutional

223. See Declaration of the Principles of International Cultural Co-operation, supra note 80; Declaration on the Use of Scientific and Technological Progress in the Interests of Peace and for the Benefit of Mankind, G.A. Res. 3384 (XXX), U.N. GAOR, 30th Sess., Supp. No. 34, U.N. Doc. A/10034 (Nov. 10, 1975); Universal Declaration on the Human Genome and Human Rights, G.A. Res. 53/152, U.N. GAOR, 53d Sess., U.N. Doc. A/RES/53/152 (Dec. 9, 1998); The Protection of Human Rights in the Context of Human Immunodeficiency Virus (HIV) and Acquired Immunodeficiency Syndrome (AIDS), C.H.R. [Commission on Human Rights] Res. 1997/33, ESCOR Supp. No. 3, at 115, U.N. Doc. E/CN.4/1997/33 (1997).

224. For a discussion of binding versus soft international law, see Dina Shelton, Introduction: Law, Non-Law, and the Problem of "Soft Law," in Commitment and Compliance: The Role of Non-Binding Norms IN tHe INTERNATIONAL LEgAL SYSTEM 1 (Dina Shelton ed., 2000), as excerpted in international Human Rights in Context: Law, Politics, Morals : TeXt and MATERIALS 165-67 (Henry J. Steiner et al. eds., 3d ed. 2008). 
frameworks. In such cases, the decisions of national courts may interpret these non-binding documents and give them legal effect through domestic law. ${ }^{225}$ These texts may also be used to help interpret international treaties that do create binding legal obligations. ${ }^{226}$

Apart from these soft-law sources, the right to science and culture also finds recognition in two international treaties: the International Covenant on Economic, Social and Cultural Rights (ICESCR) ${ }^{227}$ and the Convention on the Rights of the Child (Children's Convention). ${ }^{228}$ These instruments create legally enforceable rights claims against those nations that have signed and ratified the treaties-160 and 193 states,

225. For a discussion of the incorporation of international human rights norms into domestic constitutional law across twenty countries, see Christof Heyns \& Frans Viljoen, The Impact of United Nations Human Rights Treaties on the Domestic Level, 23 HUM. RTS. Q. 483, 490 (2001). For a more detailed discussion of such incorporation in one country context, see also Penelope E. Andrews, Incorporating International Human Rights Law in National Constitutions: The South African Experience, in PROGRESS IN INTERNATIONAL LAW 836 (Russell Miller \& Rebecca Bratspies eds., 2008) (analyzing the influence of international human rights doctrine on South African constitutional practice).

226. Shelton, supra note 224, at 166.

227. ICESCR states:

1. The States Parties to the present Covenant recognize the right of everyone:

(a) To take part in cultural life;

(b) To enjoy the benefits of scientific progress and its applications;

(c) To benefit from the protection of the moral and material interests resulting from any scientific, literary or artistic production of which he is the author.

2. The steps to be taken by the States Parties to the present Covenant to achieve the full realization of this right shall include those necessary for the conservation, the development and the diffusion of science and culture.

3. The States Parties to the present Covenant undertake to respect the freedom indispensable for scientific research and creative activity.

4. The States Parties to the present Covenant recognize the benefits to be derived from the encouragement and development of international contacts and co-operation in the scientific and cultural fields.

ICESCR, supra note 5, at art. 15(1)-(4).

228. Convention on the Rights of the Child, supra note 5, at art. 31:

1. States Parties recognize the right of the child to rest and leisure, to engage in play and recreational activities appropriate to the age of the child and to participate freely in cultural life and the arts.

2. States Parties shall respect and promote the right of the child to participate fully in cultural and artistic life and shall encourage the provision of appropriate and equal opportunities for cultural, artistic, recreational and leisure activity. 
respectively. ${ }^{229}$ Although the Children's Convention enjoys nearly universal acceptance, its recognition of the right to science and culture is rather narrower. Article 31 protects the right of the child "to participate freely in cultural life and the arts," but the document makes no mention of access to the benefits of science or protection of minor's moral and material interests in their works. ${ }^{230}$

These treaties are implemented, interpreted, and applied, first and foremost, at the domestic level. Here, different nations have adopted different approaches to the enforcement of these treaties in domestic law. At one extreme lie countries that have ratified certain treaties, yet deny their applicability in domestic law due to claims of national sovereignty or cultural relativity. Although the U.S. is a party to several human rights treaties, ${ }^{231}$ these are rarely referenced in domestic court decisions, and in some cases, the treaties have been modified at the moment of ratification to deny them any domestic legal effect. ${ }^{232}$ At

229. The U.S. has signed, but not ratified the ICESCR; it is therefore not a party until two-thirds of the Senate approves it for ratification. United Nations Treaty Collection, International Covenant on Economic, Social and Cultural Rights, status as of Jan. 1, 2010, http://treaties.un.org/Pages/ViewDetails.aspx?src=TREATY\&mtdsg no $=I V-3 \&$ chapter $=4 \&$ lang $=$ en. Only two countries have failed to ratify the Convention on the Rights of the Child: Somalia and the United Sates. United Nations Treaty Collection, Convention on the Rights of the Child, status as of Jan. 29, 2010, http://treaties.un.org/Pages/ViewDetails.aspx?src $=$ TREATY\&mtdsg_no $=I V-11 \&$ chap ter $=4 \&$ lang $=$ en. The United States is not a party to either treaty.

230. Convention on the Rights of the Child, supra note 5, at art. 31.

231. These include the following Conventions: Convention on the Prevention and Punishment of the Crime of Genocide, 78 U.N.T.S. 277 (entered into force Jan. 12, 1951, ratified Nov. 25, 1988); Convention (No. 105) Concerning the Abolition of Forced Labour, 320 U.N.T.S. 291 (entered into force Jan. 17, 1959 ratified Sept. 25, 1991); International Covenant on Civil and Political Rights, supra note 128 (entered into force Mar. 23, 1976, ratified June 8, 1992); Convention Against Torture and Other Cruel, Inhuman or Degrading Treatment or Punishment, G.A. Res. 39/46, U.N. GAOR, 39th Sess., Supp. No. 51, U.N. Doc. A/39/51 (Dec. 10, 1984) (entered into force June 26, 1987, ratified Oct. 21, 1994); International Convention on the Elimination of All Forms of Racial Discrimination, G.A. Res. 2106 (XX), U.N. GAOR, 20th Sess., Supp. No. 14, Annex, U.N. Doc. A/6014 (Mar. 12, 1966) (entered into force Jan. 4, 1969, ratified Oct. 21, 1994); Convention (No. 182) Concerning the Prohibition and Immediate Action for the Elimination of the Worst Forms of Child Labour, 2133 U.N.T.S. 161 (entered into force Nov. 19, 2000, ratified Dec. 2, 1999). For an updated listing of U.S. human rights treaty ratifications, visit Human Rights Library, University of Minnesota, Ratification of International Human Rights Treaties USA, http://www1.umn.edu/humanrts/research/ratification-USA.html (last visited Feb. 28,2010 ).

232. Of the human rights treaties ratified by the United States, the ICCPR has the widest scope in terms of the number of rights recognized. The ratification, however, was made subject to a number of reservations, including an exceptionally broad one designed to prevent individuals from invoking the rights recognized by the Covenant in U.S. courts. U.S. Reservations, Declarations and Understandings, International Covenant on Civil and Political Rights, 138 Cong. Rec. S4781-01, at Part 
the other extreme, the South African Constitutional Court has regularly looked to the ICESCR and its related General Comments as a source of applicable human rights norms, even though South Africa has never ratified this treaty. ${ }^{233}$

As these two examples suggest, ratifications alone do not tell the whole story. Judith Resnik offers a more complex account of the interaction between international human rights norms and the U.S. legal order, noting multiple ways that internationally accepted human rights norms reenter American legal discourse and impact domestic lawmaking beyond direct application of human rights treaties by the courts. ${ }^{234}$ Similarly, Melissa Waters notes a recent trend in many common law jurisdictions to incorporate international human rights norms into domestic law through a variety of mechanisms, eliding the formalist distinction between binding and non-binding instruments. ${ }^{235}$

As these accounts note, the mechanisms by which internationally accepted interpretations of human rights norms are elaborated, accepted, and applied by domestic, regional, and international bodies are complex and inescapably political. Significant differences exist between countries and across rights. Moreover, the dynamics of human rights norms application are evolving all the time. Even if a particular interpretation of a human rights norm is widely accepted by human rights scholars, the norm may nevertheless be interpreted and applied differently by a particular country's legal institutions.

Internationally accepted interpretations of human rights norms may also impact the domestic legal frameworks of countries to whom the right does not technically apply, or whose courts are reluctant to

III.1 (daily ed., April 2, 1992), http://wwwl.umn.edu/humanrts/usdocs/civilres.html (last visited Jan. 28, 2010). The unprecedented invocation of reservations led the UN Human Rights Committee to complain in 1994 that, in light of the reservations, "[n]o real international rights or obligations have thus been accepted." U.N. Int'l Covenant on Civil \& Political Rights, Human Rights Comm., Addendum: General Comment 24 (52) 1/, General Comment on Issues Relating to Reservations Made Upon Ratification or Accession to the Covenant or the Optional Protocols Thereto, or in Relation to Declarations Under Article 41 of the Covenant, para. 12, U.N. Doc. CCPR/C/21/Rev.1/Add.6 (Nov. 11, 1994).

233. See, e.g., Gov't of the Republic of $S$. Africa and Others v. Irene Grootboom and Others, No. CCT 11/2000, 2001 (1) SA 46 (CC), available at http://www.lrc.org.za/Docs/Judgments/grootboom_cc.pdf (relying on General Comments on the concept of progressive realization as it relates to the right to housing under the ICESCR to construe the nature of obligations related to the right to housing under the South African constitution).

234. See Judith Resnik, Law's Migration: American Exceptionalism, Silent Dialogues, and Federalism's Multiple Ports of Entry, 115 YALE L.J. 1564 (2006).

235. Melissa Waters, Creeping Monism: The Judicial Trend Toward Interpretative Incorporation of Human Rights Treaties, 107 Colum. L. REv. 628 (2007). 
explicitly invoke international human rights when deciding cases. The influence of international human rights norms on U.S. law is probably underestimated. To avoid political controversy, U.S. judges may frequently adopt international legal reasoning without crediting the source. ${ }^{236}$ Similarly, courts in countries with weaker traditions of judicial independence may be persuaded by human rights appeals in arguments, yet frame their decisions on less controversial grounds, such as through interpretations of statutes and regulations without explicitly invoking individual rights. ${ }^{237}$

In addition to the domestic level, there are also regional and international fora that are empowered to hear complaints that the right to science and culture has been violated. The Inter-American human rights bodies may hear individual complaints against nations that have ratified the ICESCR or the Children's Convention and also the American Convention on Human Rights, which provides the necessary recognition of jurisdiction. ${ }^{238}$ Soon, the UN Committee on Economic, Social and Cultural Rights will also begin to hear individual complaints against those nations that have ratified the new Optional Protocol to the ICESCR. ${ }^{239}$

\section{B. Implications for International IP Law}

The right to science and culture is not only about intellectual property. The conflicts between Article 27 and modern IP law, however, are particularly stark. The interpretation of Article 27 that I

236. One possible route into domestic law for the right to science and culture would be through a renewed emphasis in the common law doctrine of fair use on the importance of wide access and free participation, with reference to First Amendment rights of freedom of expression. A constitutional commitment to access could also be inferred from the Article I, Section 8's structure, which positions patent and copyright protection not has natural rights, but as privileges extended in order to benefit the broader public. See U.S. CoNST. art. I, $\S 8, \mathrm{cl} .8$.

237. Several recent cases regarding access to medicines in Egypt provide relevant examples. Hossam Bahgat \& Rebecca Wright, Access to Medicines in Egypt: A Human Rights Approach to IP, Trade and Health, in ACCESS TO KNOWLEDGE IN Egypt: New Research on InTEllectual Property, InNovation and DeVElopment 56 (Nagla Rizk \& Lea Shaver eds., 2010). In these cases, Egyptian courts reached the rights-protective result without invoking human rights by positioning their decisions as simple matters of treaty law, administrative law, and procedural correctness. Id. at 6573.

238. See Shaver, The Inter-American Human Rights System, supra note 173.

239. The Optional Protocol was adopted December 10, 2008, and opened for signatures on September 24, 2009. Communication of the Secretary General of the United Nations, Optional Protocol to the International Covenant on Economic, Social and Cultural Rights, New York, 10 December 2008, Opening for Signature, http://treaties.un.org/doc/source/signature/CN106E.pdf. 
have advocated-founded in the historical context of the UDHR's adoption and accepted principles of rights interpretation-is fundamentally at odds with the World Trade Organization's IP regime as instituted over the last ten to fifteen years. Assuming that this theory of Article 27 becomes accepted by other legal scholars and jurists, what are the implications for TRIPS and other international IP treaties?

It is not a new idea that intellectual property protection generally, or the TRIPS regime specifically, raises conflicts with human rights obligations. ${ }^{240}$ This discussion has advanced furthest in terms of examining the right to health as impacted by pharmaceutical patents. ${ }^{241}$ This Article, however, suggests there may be a broader tension between TRIPS and other treaties, which are IP-maximalist, and human rights treaties, which require careful tailoring of IP protections to avoid limiting access in ways that would constitute a violation of the right to science and culture. Is there room, within international law, for these tensions to be resolved?

On a pragmatic level, it must be noted that an imbalance exists in the two legal frameworks. Intellectual property treaties are backed by the dispute resolution system of the World Trade Organization, powerful private interests, and the frequently threatened and occasionally realized prospect of retaliatory sanctions. ${ }^{242}$ The enforcement of human rights treaties, in contrast, is left largely up to the responsibility of individual states, with weak institutional mechanisms of international accountability. ${ }^{243}$ Cautious supporters of

240. See, e.g., Sub-Comm'n on the Promotion \& Prot. of Human Rights, Resolution 2000/7, Intellectual Property and Human Rights, at para. 2, Aug. 17, 2000, available at http://www.unhchr.ch/Huridocda/Huridoca.nsf/0/c462b62cf8a07b13c1256 $9700046704 \mathrm{e}$ ?Opendocument (declaring "that since the implementation of the TRIPS Agreement does not adequately reflect the fundamental nature and indivisibility of all human rights, including the right of everyone to enjoy the benefits of scientific progress and its applications, the right to health, the right to food and the right to selfdetermination, there are apparent conflicts between the intellectual property rights regime embodied in the TRIPS Agreement, on the one hand, and international human rights law, on the other").

241. Pushed by civil society groups and developing countries, the Doha Round of trade negotiations resulted in explicit confirmation of the freedom of states within TRIPS to protect the right to health. WTO, Declaration on the TRIPS Agreement and Public Health, Ministerial Conference, 4th Sess., WTO Doc. WT/MIN(0I)/DEC/2 (2001); see also Paul Hunt, The Human Right to the Highest Attainable Standard of Health: New Opportunities and Challenges, 100 TRANSACTIONS ROYAL SOC'Y TROPICAL MED. \& HYGIENE 603 (2006).

242. See generally Joost Pauwelyn, Enforcement and Countermeasures in the WTO: Rules are Rules-Toward a More Collective Approach, 94 AM. J. INT'L. L. 335 (2000).

243. See generally Harold Hongju Koh, How is International Human Rights Law Enforced?, 74 IND. L.J. 1397 (1999). 
human rights might conclude that it is better not to court conflict, by narrowly construing the right to science and culture. Advocates of expansive IP protections might also find support for such an approach through arguments that the more specific norms of TRIPS, for instance, should be given priority over the less specific norms of the human rights treaties.

On a philosophical level, however, the argument may be made that human rights norms take priority over trade rules, on the basis of their status not only as reflections of positive law, but also natural law. These obligations exist not only because states have signed a treaty, but also for reasons inherent to human liberty and dignity. On this view, national judges should resolve disputes according to these highest principles, with lower regard for any gap between such decisions and the requirements of international IP treaties. International law scholar Thomas Cottier takes issue with this approach, however, on philosophical as well as pragmatic grounds. The issue of normative hierarchy is not so simple, he argues. Not all elements of international human rights law carry equal normative weight, while some elements of trade law-such as the principle of nondiscrimination-express fundamental principles similar to some elements of human rights law. ${ }^{244}$

Once a tension between the international IP framework and the international human rights framework is admitted, resolving it is not a simple task. Allowing international trade law to define the limits of the right to science and culture would defeat its very purpose as a meaningful limit on state action. Neither, however, can human rights arguments ignore the reality of international trade agreements. The challenge is come up with an approach to coordination of the two bodies of law that neither renders the human rights norm meaningless, nor fundamentally upsets the multilateral bargain of the WTO framework.

The call for such reconciliation lands us in the middle of an ongoing political and scholarly debate about the constitutionalization of WTO law. ${ }^{245}$ Put simply, the letter of WTO trade rules often bumps up against competing priorities which command widespread concern, including public health, labor rights, and environmental protection. This has prompted calls for WTO dispute resolution to move beyond narrow interpretation and application of its own rules to take account of

244. Thomas Cottier, Trade and Human Rights: A Relationship to Discover, 5 J. INT'L. ECON. L. 111, 114 (2002).

245. See generally Deborah Z. Cass, The Constitutionalization of the World TRade ORganization: Legitimacy, Democracy, and COMMUNity IN THE INTERNATIONAL TRADING SYSTEM (2005) (reviewing the debate and distinguishing different dimensions of constitutionalization at issue). 
additional sources of law and members' public policy priorities. Scholarly observers disagree on the extent to which such constitutionalism is desirable, what form it should best take, the extent to which it has already been achieved, and the likelihood that it will advance in the future ${ }^{246}$ What may safely be concluded at this point is that the extent to which the WTO can and should take account of human rights concerns is an issue of ongoing debate and uncertainty, and whatever the case today, the situation may be dramatically different ten or twenty years from now.

The waters are less murky, however, with respect to areas of IP policy that fall within the area of state flexibility still allowed by TRIPS. Many countries have implemented or are considering forms and levels of domestic IP protection that go beyond the requirements of international IP law. ${ }^{247}$ Judicial scrutiny of such "TRIPS-plus" protections on human rights grounds does not raise concerns of conflicts between treaties. Strategically, access to knowledge advocates would be well advised to begin their impact litigation efforts by advancing cases that promote IP reforms clearly not in conflict with existing international trade obligations. Only once domestic courts are familiar with the access arguments and comfortable that they understand the implications of the right to science and culture well should cases requiring more delicate balancing with the international IP regime even be considered. Otherwise the risk is too great that the courts will simply seek to avoid controversy by narrowly interpreting the human rights obligations.

It may take a decade, or longer, to develop the normative content of the right to science and culture to the point that it can mount a direct challenge to the existing international IP regime. This should not be a cause for dismay; large shifts in international law take time. As

246. See, e.g., id.; Susan Ariel Aaronson, Seeping in Slowly: How Human Rights Concerns are Penetrating the WTO, 6 WORLD TRADE Rev. 1 (2007); Philip Alston, Resisting the Merger and Acquisition of Human Rights by Trade Law: A Reply to Petersmann, 13 EUR. J. INT'L L. 815, 816 (2002) (arguing that "the result of following [Petersmann's] approach would be to hijack, or more appropriately to Hayek, international human rights law"); Cottier, supra note 244; Daniel Esty, Good Governance at the Supranational Scale: Globalizing Administrative Law, 115 Y ALE L.J. 1490 (2006); Sheldon Leader, Trade and Human Rights II, in 1 THE WorLd Trade Organization: Legal, Economic and Political ANalysis, (Patrick F.J. Macrory et al. eds., 2005); Ernst-Ulrich Petersmann, The WTO Constitution and Human Rights, 3 J. INT'L ECON. L. 19 (2000) (suggesting that integration of human rights norms at the WTO may be relatively unproblematic due to strong compatibility between the two bodies of law); Joel P. Trachtman, The Constitutions of the WTO, 17 EUR. J. INT'L L. 623 (2006).

247. For examples of such TRIPS-plus legislation and regulation in two countries, see generally ACCESS TO KNOWLEDGE IN BRAZIL, supra note 7, and ACCESS TO KNOWLEDGE IN EGYPT, supra note 7. 
Laurence Helfer notes, the development of counterregime norms in fora not traditionally known for IP policymaking may yield few immediate results, but over time can be effective as part of a long-term strategy to critique and destabilize the dominant IP regime. ${ }^{248}$ Efforts invested in developing the right to science and culture perspective through national courts and international human rights institutions may take decades to realize their full effect. The strength of the eventual impact will depend on other developments not yet apparent, such as the outcome of the WTO constitutionalization debate, and the WIPO Development Agenda.

\section{CONCLUSION}

Sixty years ago, delegates from all the nations of the world came together to sign a statement of universal principles, which were to be the basis of an international legal regime dedicated to social justice and international cooperation. On at least one dimension, we must acknowledge that this project has not been a great success. Article 27 of the Universal Declaration articulated a commitment to treat science and culture as global public goods. In this vision, cooperation and collaboration were touchstone concepts and access the birthright of every individual. In the succeeding decades, however, a competing international legal regime has gained dominance that is fundamentally at odds with this vision.

Embodied in TRIPS and numerous bilateral and multilateral trade agreements, this regime seeks to treat every instance of science and culture as private property. ${ }^{249}$ By privileging private interests over public ones, the modern IP regime broadly fails to respect the "access" dimension of the right to science and culture. By reducing the moral and material interests of authorship to alienable property rights, it equally fails to deliver on the "protection" dimension. Yet, apart from some hard-won concessions in the area of health, the international human rights framework has fundamentally failed to shape or constrain this new and contradictory legal regime.

The right to science and culture may serve as an important tool for rebalancing international IP law, enabling greater realization of the public good dimensions of knowledge. Toward that end, this Article has offered a theory of this long-neglected right that emphasizes universal access, and protection of authors' interests rather than protection of intellectual property per se. This understanding ultimately

248. Helfer, supra note 19 , at 82 .

249. The exceptions to this general rule-including traditional knowledge and genetic resources in the wild-are notable. These are precisely the scientific and cultural resources of greatest commercial value that lie in politically weaker states. 
can serve as a framework for renewed scrutiny-including judicial review-of the consistency of IP policies with the public interest. 